Essay

\title{
THE UNINTENDED CONSEQUENCES OF ENHANCING GUN PENALTIES: SHOOTING DOWN THE COMMERCE CLAUSE AND ARMING FEDERAL PROSECUTORS
}

\author{
SARA SUN BEALE $\dagger$
}

\section{INTRODUCTION}

To deter gun violence and punish gun offenders, Congress-like state legislatures-has repeatedly increased the penalties for illegal gun possession and the use of guns in the commission of other crimes. After several rounds of statutory increases, the penalties are now much higher than penalties for criminal conduct that accompanies gun possession and also very high relative to penalties for other serious offenses. By designating separate penalties for gun use, as high or higher than the penalties for many of the most serious traditional offenses, Congress has sent a deterrent message to would-be offenders and sought to incapacitate those who will not be deterred. Whether this message has been successful in altering the behavior of those who might otherwise commit gun offenses is an empirical question that other researchers are attempting to answer. ${ }^{1}$

Copyright (C) 2002 by Sara Sun Beale.

$\dagger \quad$ Charles L.B. Lowndes Professor, Duke University School of Law. An earlier version of this Essay was presented at the University of Arizona's conference on Guns, Crime, and Punishment in America. The author gratefully acknowledges the comments of Allan Ides, Robert Mosteller, Stephanos Bibas, Neal Katyal, Julie O'Sullivan, and the faculties at Georgetown University Law Center and Ohio State University College of Law, which provided an opportunity to present this Essay as a work in progress.

1. For a helpful review of the research, see Paul J. Hofer, Federal Sentencing for Violent and Drug Trafficking Crimes Involving Firearms: Recent Changes and Prospects for Improvement, 37 AM. CRIM. L. REV. 41, 43-45 (2000) (concluding that as a whole firearms sentence enhancement laws "show little or no impact," though enhancement laws have been "associated with a decrease in some types of crimes in a few states"). 
Although Congress intended to alter the behavior of would-be criminals or incapacitate them, it has created behavior-altering incentives for other actors in the criminal justice system as well. This Essay explores how the legislative attempts to crack down on gun violence have affected the behavior of judges and prosecutors, and what legal issues, outcomes, and concerns these attempts have generated.

In Part I, I explore how the pressure to enhance gun penalties has affected the boundary between federal and state law, raising both constitutional and prudential issues. I argue that this pressure was a critical factor leading to a historic ruling limiting the constitutional scope of federal jurisdiction under the Commerce Clause, as the Supreme Court responded to the potential for institutional damage to the federal courts. At the administrative (or prosecutorial) level, there has been pressure on the definition of the offenses in question, as federal prosecutors have sought to construe these firearms statutes broadly to secure enhanced sentences in a wider range of cases. As the example of Richmond's Project Exile reveals, ${ }^{2}$ these pressures also have the potential to reshape the character of federal law enforcement.

In Part II, I explore the pressure gun-related penalties have placed on a different boundary, the line defining the elements of an offense. I argue that prosecutors have pressed vigorously for expansive interpretations of the elements of the most commonly prosecuted federal firearm offense, the felon-in-possession statute, to expand the range of cases in which the enhanced penalties may be imposed. In an unusual volume of litigation, prosecutors have successfully expanded the effective scope of the statute. A review of prosecutorial practices also reveals an apparently conflicting trend: federal prosecutors bargain away or decline to bring charges under the enhanced penalties in the majority of cases. Thus, enhancing the penalties available under federal law and expanding the range of cases to which those penalties apply also has enhanced the prosecution's bargaining power and its unchecked discretion in a wide range of cases.

\section{PRessure on the Boundary Between FEDERAL AND STATE LAW}

One of the most obvious boundary lines affected by the pressure to increase the punishment for gun crimes is the boundary separating

2. See infra Part I.B. 
federal and state criminal law. The general police power is reserved to the states; both constitutional design and tradition have narrowly limited the scope of federal criminal law. ${ }^{3}$ Local crime has traditionally been regarded as the province of the states, and federal criminal jurisdiction has been the exception rather than the rule. In the last third of the twentieth century, however, a plethora of new federal criminal statutes strained the general principle of leaving the prosecution of local crime to the states. ${ }^{4}$ Some of the most significant statutes extending the scope of federal criminal jurisdiction involve firearms offenses-and some legislative proposals would expand jurisdiction even further. These new laws, which make federal crimes of conduct already illegal under state law, have generally been intended to impose harsher penalties than those currently available under state law.

Section A begins by describing the legislative initiatives. Since 1968 Congress has pressed the policy and constitutional limits of federal jurisdiction in efforts to extend federal firearms provisions to a broader range of violent crime under the Commerce Clause. The Supreme Court has responded to these legislative changes. In the main, the Supreme Court's gun-related decisions have involved statutory construction. The Court repeatedly has read federal firearms legislation narrowly, thereby reducing its scope and impact. More importantly, the Court also issued its most important Commerce Clause opinion in fifty years in a federal firearms case. Although each of these decisions may be explained on other grounds, together they suggest an institutional response by the Court to the threat that federalizing gun-related crime could swamp the federal courts and alter their fundamental character.

As discussed in Section B, federal prosecutors also have pushed the envelope by interpreting the firearms statutes expansively and by using their charging discretion to accommodate a larger number of firearms cases. Both legislative and executive activity directed at enhancing the sentences for gun offenders have expanded-and arguably distorted - the traditional territory of federal criminal law.

3. For an account of the history of federal criminal law, see generally TASK FORCE ON the Federalization of Criminal Law, Am. BAR Ass'N, The Federalization of CRIMINAl LAW 5-12 (1998) [hereinafter TASK FORCE]; Sara Sun Beale, Federal Criminal Jurisdiction, in 2 ENCYCLOPEDIA OF CRIME AND JUSTICE 694 (Joshua Dressler ed., 2002).

4. In 1998, the American Bar Association's Task Force on the Federalization of Criminal Law reported that more than forty percent of the federal criminal statutes adopted since the Civil War have been enacted since 1970. TASK FORCE, supra note 3, at 7. 


\section{A. Legislative Initiatives and Judicial Responses}

The modern era of federal firearms legislation began in 1968 after the assassinations of Robert Kennedy and Martin Luther King, Jr. That year, Congress expansively employed its authority under the Commerce Clause to reach a wide range of gun-related crime. For present purposes, the most important provision of the 1968 legislation made it a federal crime for a previously convicted felon to possess a firearm. ${ }^{5}$ The Department of Justice interpreted the statute as extending federal jurisdiction to any felon who possessed a firearmwith no showing required in individual cases of any connection to interstate commerce or any other basis for federal jurisdiction-and the lower courts accepted this interpretation. ${ }^{6}$ So interpreted, the federal felon-in-possession statute and the loan-sharking statute also enacted in $1968^{7}$ were the first federal criminal statutes to employ the class-of-activities model to assert criminal jurisdiction under the Commerce Clause. In a pair of decisions in 1971, the Supreme Court upheld the class-of-activities approach in the loan-sharking statute, ${ }^{8}$ but it finessed the issue in a case involving the felon-in-possession statute. Noting that the lower courts' interpretation of the felon-inpossession statute would work a major change in the boundary between federal and state law, ${ }^{9}$ the Supreme Court sidestepped the constitutional and policy issues posed by this expansive reading of the statute. Finding the statutory language and the legislative history ambiguous, the Supreme Court applied the rule of lenity and declined

5. Title VII of the Omnibus Crime Control and Safe Streets Act of 1968, Pub. L. No. 90351, $\S ~ 1201-1203$, 82 Stat. 197, 236-37 (repealed 1986) provided in pertinent part:

Any person who-

(1) has been convicted by a court of the United States or of a State or any political subdivision thereof of a felony .... and who receives, possesses, or transports in commerce or affecting commerce... any firearm shall be fined not more than $\$ 10,000$ or imprisoned for not more than two years, or both.

6. See United States v. Bass, 404 U.S. 336, 338 (1971) ("The Government proceeded on the assumption that $\S 1202$ (a)(1) banned all possessions and receipts of firearms by convicted felons, and that no connection with interstate commerce had to be demonstrated in individual cases."); id. at 338 n.3 (noting that five courts of appeals, with only one dissenting judge, accepted the government's interpretation, and that only the Second Circuit and a few district courts disagreed); see also Robert L. Stern, The Commerce Clause Revisited-The Federalization of Interstate Crime, 15 ARIZ. L. REV. 271, 280-81 (1973) (discussing the government's interpretation).

7. Consumer Credit Protection Act, Pub. L. No. 90-321, 82 Stat. 146, 159 (1968) (codified as amended at 18 U.S.C. $\S \S 891-896(2000))$.

8. Bass, 404 U.S. at 338; Perez v. United States, 402 U.S. 146, 154-57 (1971).

9. Bass, 404 U.S. at $349-50$. 
to "assume that Congress meant to effect a significant change in the sensitive relation between federal and state criminal jurisdiction." 10 The 1968 legislation thus illustrates either Congress's willingness to press its authority under the Commerce Clause to the limit to reach felons who possess firearms, ${ }^{11}$ or the Justice Department's zeal to interpret an ambiguous statute in these terms, thereby raising both the constitutional and interpretative question.

The Supreme Court's interpretation of the 1968 legislation typifies its response to many of the federal firearms statutes. Despite the Court's strong law-and-order orientation in the last twenty-five years, it has interpreted the various federal firearms statutes to restrict their scope and impact. ${ }^{12}$ Several of these decisions are discussed in Part II.

More recently, Congress authorized federal criminal jurisdiction over another class of activities-gun possession in a school zonepursuant to its power to regulate interstate commerce. The Gun-Free School Zones Act of 1990 made it a federal offense "for any individual knowingly to possess a firearm at a place that the individual knows, or has reason to believe, is a school zone." ${ }^{\prime 13}$ A schoolboy's prosecution under this act prompted the Supreme Court's decision in United States v. Lopez, ${ }^{14}$ the first Commerce Clause decision in more than half a century striking down a federal statute. Lopez sent a shock wave through both the judiciary and the academy, and set off an enormous wave of litigation challenging a wide variety of other federal criminal statutes, including other gun laws, on constitutional

\footnotetext{
10. Id.

11. For a discussion of the novelty of the class-of-activities legislation, see Stern, supra note 6 , at $280-84$.

12. See, e.g., Bailey v. United States, 516 U.S. 137, 150 (1995) (holding that "use" under 18 U.S.C. § 924(c) requires active employment); Staples v. United States, 511 U.S. 600, 619 (1994) (holding that, in a prosecution under 26 U.S.C. $\$ 5861$ (d) for possession of an unregistered firearm, the government must prove the defendant knew his firearm had characteristics that brought it within the statutory definition of a machine gun); Busic v. United States, 446 U.S. 398, 399-400 (1980) (finding that a sentence for § 924(c) may not be imposed in a prosecution for assault on a federal officer under 18 U.S.C. $\S 111$, which provides for an enhanced sentence when a defendant "uses" a deadly weapon); Simpson v. United States, 435 U.S. 6, 16 (1978) (holding that a sentence for a $\S 924$ (c) violation may not be imposed in a prosecution for bank robbery under 18 U.S.C. $\$ 2113$, which provides for an enhanced sentence when robbery is committed "by the use of a dangerous weapon or device"). But see Scarborough v. United States, 431 U.S. 563, 566-67 (1977) (holding that proof that a firearm has traveled at some time in interstate commerce is sufficient under 18 U.S.C. App. § 1202(a)).

13. 18 U.S.C. $§ 922(q)(1)(A)(1988 \&$ Supp. V 1993).

14. 514 U.S. 549 (1995).
} 
grounds. ${ }^{15}$ At first it appeared that Lopez might be "a derelict on the waters of the law," ${ }^{16}$ as the lower courts generally read the Supreme Court's decision narrowly and upheld the challenged laws. ${ }^{17}$ But five years later the Supreme Court, following Lopez, struck down a key provision of the Violence Against Women Act (VAWA) in United States v. Morrison. ${ }^{18}$ Lopez and Morrison provide a doctrine with which the Supreme Court can prune back federal criminal jurisdiction, particularly in cases involving conduct the Court deems noneconomic. $^{19}$

In light of Congress's efforts to saddle the federal courts with many new criminal cases, positive political theory ${ }^{20}$ provides a convincing explanation for a series of Supreme Court decisions culminating in Lopez and Morrison. Applying and adapting positive political theory, William Eskridge and Philip Frickey have argued that the Supreme Court should be understood as a rational, self-interested actor interacting with the other branches of government. ${ }^{21}$ Reviewing the Court's 1993 Term, they identified two criminal cases they believe

15. 1 Sarah N. Welling, Sara Sun Beale \& Pamela H. Bucy, Federal Criminal LAW AND Related ACTIONS: CRimes, Forfeiture, tHe FAlse Claims ACt, AND RICO § 1.3(B)(iii) (1998 \& Supp. 2000).

16. See Lambert v. California, 355 U.S. 225, 232 (1957) (Frankfurter, J., dissenting) ("I feel confident that the present decision will turn out to be an isolated deviation from the strong current of precedents-a derelict on the waters of the law.").

17. Welling, BeAle \& BuCY, supra note 15, § 1.3(B)(iii). See generally Glenn H. Reynolds \& Brannon P. Denning, Lower Court Readings of Lopez, or What If the Supreme Court Held a Revolution and Nobody Came?, 2000 WISC. L. REV. 369 ("[L]ower courts have tended to limit Lopez to its facts ....").

18. 529 U.S. 598, 627 (2000) (holding that Congress exceeded its authority under the Commerce Clause-and under Section 5 of the Fourteenth Amendment-in enacting the civil cause of action under the Violence Against Women Act, 42 U.S.C. § 13981).

19. For a discussion of Morrison and its likely impact on federal criminal jurisdiction, see WELLING, BEALE \& BUCY, supra note 15, § 1.3 (iv)-(v) (2000 Supp.). The four dissenters in Morrison argued that "[t]he 'economic/noneconomic distinction' is not easy to apply." 529 U.S. at 656 (Breyer, J., dissenting).

20. There is considerable disagreement on the precise contours of positive political theory, especially as it relates to public choice. See Daniel A. Farber \& Philip P. Frickey, Foreword: Positive Political Theory in the Nineties, 80 GEO. L.J. 457, 458-63 (1992) (describing varying views). Farber and Frickey conclude that positive political theory "consists of non-normative, rational-choice theories of political institutions." Id. at 462 (emphasis omitted). For an earlier positive-political-theory reading of Lopez, see generally Barry Friedman, Legislative Findings and Judicial Signals: A Positive Political Reading of United States v. Lopez, 46 CASE W. RES. L. REV. 757 (1996).

21. William N. Eskridge, Jr. \& Philip P. Frickey, The Supreme Court, 1993 Term-Foreword: Law as Equilibrium, 108 HARV. L. REV. 26, $28-29$ (1994); see also Friedman, supra note 20, at 776 (arguing that positive political theory "presumes that institutions, or at least institutional actors, have policy preferences and that political institutions act rationally in a manner calculated to advance those preferences"). 
departed from the Court's normal rules of statutory interpretation to signal "the Court's extreme displeasure with Congress." 22 As Eskridge and Frickey noted, "From the standpoint of political theory, we should expect the Court to react with hostility when Congress loads up the dockets of the already-swamped federal courts with criminal cases, which must receive priority scheduling, especially when the crimes have no special national significance or regulatory interest."23 Eskridge and Frickey concluded that the decisions in question are "difficult to square" with the Court's rule-of-law values, and that the decisions demonstrate the importance the Court places on the values of "federalism and ... the business of the federal judiciary." ${ }^{24}$ Writing one year before Lopez, they summed up the Court's response to the increasing federalization of crime:

In this area, the Court and Congress are at loggerheads, and the Court may feel that it must communicate its concern to Congress clearly.... [I]n this area the Court is an active opponent of Congress and seems to be throwing up what roadblocks it can. In addition, because there are few interest groups to derail feel-good, dosomething federal crime bills, the Court may sense that it alone is left to confront Congress.

Other observers have suggested that the federal courts had a second institutional interest at stake when Congress sought to enlarge the scope of federal criminal jurisdiction: status and dignity. These dignity concerns, it is suggested, caused the federal judiciary (and its supporters) to distinguish sharply between the cases of national import that should be heard in the federal courts and the ordinary street crimes historically prosecuted in the state courts. ${ }^{26}$

22. Eskridge \& Frickey, supra note 21, at 69-70 (discussing Staples v. United States, 510 U.S. 600 (1994) and Ratzlaf v. United States, 510 U.S. 135 (1994)).

23. Id. at 70 .

24. Id. at $70-71$.

25. Id. at 71 .

26. E.g., Rory K. Little, Myths and Principles of Federalization, 46 Hastings L.J. 1029, 1055-61 (1995); Judith Resnik, Trial as Error, Jurisdiction as Injury: Transforming the Meaning of Article III, 113 HARV. L. REV. 924, 967-95 (2000). As Professor Resnik's historical discussion establishes, the sense of the elevated mission of the federal courts and the concern that they could be deluged by a large number of minor cases are not new. See also Edward A. Purcell, Jr., Reconsidering the Frankfurterian Paradigm: Reflections on Histories of the Lower Federal Courts, 24 LAW \& SOC. INQUIRY 679, 708-09 (1999) (quoting a letter written in 1924 by a federal district judge who lamented the loss of the "dignity and honor" of the federal bench, and stated that due to the influx of Prohibition cases and "new" immigration, the federal courts appeared to be police courts). 
Workload and dignity concerns combined in claims that the federal courts were in danger of becoming "police courts." ${ }^{27}$ Use of the term "police court" ${ }^{\prime 2}$ raised the specter of high-volume urban courts where vast numbers of cases are processed in an assembly-line fashion reminiscent of traffic court, ${ }^{29}$ where individual adjudication is impossible, and where due process exists more in theory than in practice. ${ }^{30}$ Thus, status or dignity concerns, intertwined with workload

27. See, e.g., Paul D. Carrington, The Federal War on Drugs: Time for a Reality Check?, 14 T.M. COOLEY L. REV. 179, 185 (1997) (arguing that "[f]ederal courts are increasingly police courts, while antitrust and employment discrimination laws are being enforced by arbitrators who are not accountable for their fidelity to law"); Proceedings of the Western Regional Conference on State-Federal Judicial Relationships, 155 F.R.D. 233, 290 (1993) (noting that "leaders of the organized bar tend to support the federal judges who decry the trend to turn federal courts into police courts"); Sanford H. Kadish, Comment, The Folly of Overfederalization, 46 HAstings L.J. 1247, 1250-51 (1995) (citing former American Bar Association [ABA] President Robert Raven and Judge Judith Keep, who describe how the federal district court in San Diego is "'sinking in a mire of criminal cases' that has turned it largely into a 'police court' where judges are under "constant pressure to keep cases moving as fast as possible"').

28. Technically, a police court (also called a magistrate's court) has trial jurisdiction over only minor criminal offenses, as well as "the power to bind over for trial persons accused of more serious offenses." BLACK's LAW DICTIONARY 359 (7th ed. 1999) (defining “magistrate's court" under "court").

29. See, e.g., Kathleen F. Brickey, Criminal Mischief: The Federalization of American Criminal Law, 46 HASTINGS L.J. 1135, 1170 n.186 (1995) (arguing that federal drug policies risk turning "federal courts into police courts that dispense assembly line justice").

30. A sense of what the term "police court" implies can be gleaned from the Supreme Court's decision in Argersinger v. Hamlin, 407 U.S. 25 (1972). In a passage describing the adjudication of misdemeanors and petty crimes, and referring to "police courts," the Court quoted the following passage from the President's Commission on Law Enforcement and Administration of Justice:

An inevitable consequence of volume that large is the almost total preoccupation in such a court with the movement of cases. The calendar is long, speed often is substituted for care, and casually arranged out-of-court compromise too often is substituted for adjudication. Inadequate attention tends to be given to the individual defendant, whether in protecting his rights, sifting the facts at trial, deciding the social risk he presents, or determining how to deal with him after conviction. The frequent result is futility and failure. As Dean Edward Barrett recently observed:

"Wherever the visitor looks at the system, he finds great numbers of defendants being processed by harassed and overworked officials. Police have more cases than they can investigate. Prosecutors walk into courtrooms to try simple cases as they take their initial looks at the files. Defense lawyers appear having had no more than time for hasty conversations with their clients. Judges face long calendars with the certain knowledge that their calendars tomorrow and the next day will be, if anything, longer, and so there is no choice but to dispose of the cases.

"Suddenly it becomes clear that for most defendants in the criminal process, there is scant regard for them as individuals. They are numbers on dockets, faceless ones to be processed and sent on their way. The gap between the theory and the reality is enormous. 
concerns, gave the Supreme Court an institutional interest in opposing congressional federalization of crime, particularly low-status, high-volume crimes.

A few months after the publication of Eskridge and Frickey's article, Congress considered-and came within a hair's breadth of adopting - a proposal to expand federal jurisdiction over gun-related crime to unprecedented levels. In the early 1990s, Senator Alfonse D'Amato began to champion the idea of making every crime committed with a gun that had crossed state lines a federal offense. ${ }^{31}$ Because firearms are made in only a few locations and most are shipped across state lines, this proposal would have extended federal jurisdiction to nearly every one of the 900,000 gun offenses that occur each year in the United States. ${ }^{32}$ The 900,000 potential federal offenses dwarfed the total federal criminal caseload at that time, which was less than 50,000 cases. $^{33}$ Opponents in the Senate argued that this proposal would require quadrupling the number of federal judges, the number of federal prosecutors, and the FBI's budget. ${ }^{34}$ D'Amato predicted that the number of prosecutions and the burden on the system would be far lower, but he also stated his willingness to enlarge the Justice Department and federal courts as necessary to "get these violent predators off the streets." ${ }^{35}$ Senator D'Amato also proposed legisla-

\footnotetext{
"Very little such observation of the administration of criminal justice in operation is required to reach the conclusion that it suffers from basic ills."

Id. at 34-35 (quoting PRESIDENT's COMM'N ON LAW ENFORCEMENT \& ADMIN. OF JUSTICE, THE CHALlENGE OF CRIME IN A FREE SOCIETY 128 (1967)).

Problems of this nature still exist. A more recent report evaluating the New York City Criminal Court found that the court performed "a largely clerical role, moving cases rather than dispensing justice," trying only $0.4 \%$ of cases, and providing no more than the packaging of the due process model, empty of contents. Harry I. Subin, The New York City Criminal Court: The Case for Abolition 4-5 (Center for Research in Crime and Justice, New York University School of Law, Occasional Papers No. XII, 1992).

31. See 139 CONG. REC. 28,223-24 (1993) (proposing amendment 1147, which would create a new federal offense of murder with a firearm that has traveled in interstate or foreign commerce and an amendment of 18 U.S.C. $\$ 924$ (c) to include possession or use of a firearm during and in connection with a state crime of violence or drug-trafficking crime); 137 CONG. REC. 16,830 (1991) (proposing an amendment to the Guns and Violence Against Women Act of 1991 to create a federal offense of committing a crime with a firearm that has crossed state lines).

32. 140 CONG. REC. 11,178 (1994) (statement of Sen. Biden).

33. Id. at 11,180 (noting that the federal criminal caseload was then 48,366 ).

34. E.g., id.

35. Id. at 11,181 (statement of Sen. D'Amato) (arguing that the caseload would likely increase by 2,300 rather than 30,000 ; noting that if the caseload increased by 30,000 , local prosecutors could be cross-designated; and concluding that "whatever the increase in judges is necessary to keep our judicial system from breaking down, this Senator will vote for it. The same with prosecutors, the same with prisons").
} 
tion making it a federal crime punishable by death to commit a murder with a handgun that had traveled in interstate or foreign commerce. ${ }^{36}$ D'Amato's proposals passed in the Senate in $1991,{ }^{37}$ but the bill in question died when Senate cloture motions repeatedly failed. ${ }^{38}$ In 1994, the Senate again passed the D'Amato proposals ${ }^{39}$ as amendments to the bill that ultimately became the Violent Crime and Law Enforcement Act. ${ }^{40}$ Although both the House and the Senate voted to instruct their conferees to insist on the inclusion of these provisions, ${ }^{41}$ the conferees omitted the provisions, and the Senate accepted the House version, which did not contain the D'Amato proposals. ${ }^{42}$

The federal judiciary vigorously opposed Senator D'Amato's proposals. In 1991, Chief Justice William Rehnquist wrote to Congress to express the Judicial Conference's opposition. ${ }^{43}$ The Chief Jus-

36. 139 CONG. REC. 28,222-24 (1993) (statement of Sen. D’Amato) (proposing amendment 1147).

37. See 137 CONG. REC. 16,561 (1991) (passing an amendment creating a federal offense of murder involving a firearm by a vote of 65-33); id. at 16,835 (passing an amendment creating a federal offense of use, possession, or carrying a firearm during and in relation to any state crime of violence or drug-trafficking offense by a vote of 88-11).

38. Cloture motions on the conference report failed in the Senate on November 27, 1991, and on March 19 and October 2, 1992. Id. at 36,128; 138 CONG. REC. 6,127 (1992); id. at 30, 287.

39. See 139 CONG. REC. 28,246 (1993) (approving the D'Amato amendment by a vote of 58-42).

40. Violent Crime Control and Law Enforcement Act of 1994, Pub. L. No. 103-322, 108 Stat. 1796 (codified in scattered sections of 18 U.S.C. and 42 U.S.C.).

41. See 140 CONG. REC. 11,179 (1994) (D'Amato motion); id. at S6099 (Biden summary of D'Amato motion); id. at 11,195 (passing D'Amato motion by a vote of 51-47); id. at 17,235 (introducing the McCollum motion, which instructed House managers not to agree to any provision not including $\S 2405$ of the Senate amendment, which would make it a federal crime to use or possess a firearm during a state crime of violence or drug trafficking); id. at 17,238 (agreeing to McCollum motion by a vote of 291-128).

42. H. R. Conf. ReP. No. 103-711 (1994); H. R. Conf. ReP. No. 103-694 (1994). Senator D'Amato voted against the conference report. 140 CONG. REC. 24,114-15 (1994) (Vote No. 295).

43. The Chief Justice, writing in his capacity as presiding officer of the Judicial Conference, submitted to Congress the following statement:

The Judicial Conference of the United States opposes legislation adopted by the Senate which would expand federal criminal law jurisdiction to encompass homicides and other violent state felonies if firearms are involved. Such expansion of federal jurisdiction would be inconsistent with long-accepted concepts of federalism, and would ignore the boundaries between appropriate state and federal action.

The addition to federal jurisdiction of virtually any crime committed with a firearm that has crossed a state line will swamp the federal courts with routine cases that states are better equipped to handle, and will weaken the ability of the federal courts effectively to deal with difficult criminal cases that present uniquely federal issues.

Not only will bona fide federal criminal prosecutions suffer if the Senate's expansive firearms provisions are adopted, but federal courts, overburdened by criminal cases, 
tice also highlighted his opposition in his 1991 report on the federal courts, ${ }^{44}$ arguing that federalizing these crimes would have been "inconsistent with long-accepted concepts of federalism, ... would have swamped federal prosecutors, thus interfering with other federal criminal prosecutions, and would have ensured that the already overburdened federal courts could not provide a timely forum for civil cases." ${ }^{45}$ The Chief Justice made similar comments in various public statements throughout the period that the D'Amato proposals were under consideration in Congress. ${ }^{46}$ In 1994, testifying before the Sen-

will be unable to carry out their vital responsibilities to provide timely forums for civil

cases.

140 CONG. REC. 11,177-78 (1994) (reprinting the letter dated Sept. 19, 1991, and the enclosed statement). For an interesting article identifying the federal judiciary's institutional interests and suggesting that it should not lobby Congress about jurisdictional provisions, see Lauren Robel, Impermeable Federalism, Pragmatic Silence, and the Long Range Plan for the Federal Courts, 71 IND. L.J. 841 (1996).

44. William H. Rehnquist, Chief Justice's 1991 Year-End Report on the Federal Judiciary, THIRD BRANCH, Jan. 1992, at 1, 3.

45. Id.

46. See, e.g., Chief Justice Addresses ABA Midyear Meeting, THIRD BRANCH, Feb. 1992, at 1-2 (describing Rehnquist's remarks opposing the D'Amato amendment-which he noted did not pass in the prior year but "may resurface"); William H. Rehnquist, Convocation Address, Wake Forest University (Oct. 25, 1994), in 29 WAKE FOREST L. REV. 999, 1002-05 (1994) (describing the extension of federal criminal jurisdiction in the 1994 crime bill and noting his own doubts "as to the wisdom of some of these provisions"); William H. Rehnquist, Seen in a Glass Darkly: The Future of the Federal Courts, Address Before the University of Wisconsin Law School (Sept. 15, 1992), in 1993 WIS. L. REV. 1, 6-7 [hereinafter Rehnquist, Seen in a Glass]:

Most federal judges have serious concerns about the numbers and types of crimes now being funnelled into the federal courts. They question the appropriateness of handling "street crimes" formerly handled in the state systems; they note the impact on their civil caseloads; and they point to the serious drain on the judiciary's resources. On the other hand, federalization of crimes has had enormous political appeal over the past decade, and hardly a congressional session goes by without an attempt to add new sections to the federal criminal code. The attorney general has made increased federal criminal prosecutions a centerpiece of his crime-fighting policy. Although the judiciary successfully opposed proposals last session that would have federalized virtually any murder committed with a firearm, similar proposals are likely to resurface. Continuation of the current trend toward large-scale federalization of the criminal law has the enormous potential of changing the character of the federal judiciary. Therefore, the Long Range Planning Committee hopes that there will be wide-scale debate over two important questions: What should be required to make an offense a federal crime?; and Should certain categories of criminal offenses now prosecuted in the federal courts more appropriately be shifted to the state courts?

William H. Rehnquist, Welcoming Remarks: National Conference on State-Federal Judicial Relationships, Address Before the National Conference on State-Federal Judicial Relationships (Apr. 10, 1992), in 78 VA. L. REV. 1657, 1660 (1992) (calling for "congressional self-restraint . . . in the federalization of crimes" and citing the D'Amato amendment as an example of the "recent tendency to federalize crimes for essentially political reasons without recognizing the impact federalization would have on the federal courts"). 
ate Appropriations Committee, Justice Anthony Kennedy expressed concern that the D'Amato proposals would turn the federal judiciary into "police courts." ${ }^{47}$ Justice David Souter noted that a significant expansion of the federal courts' criminal jurisdiction could incapacitate the courts. ${ }^{48}$ The Administrative Office of the U.S. Courts, which opposed the D'Amato proposals, estimated that their enactment would generate 200,000 new cases in the federal system. ${ }^{49}$ Opponents in the House argued that the proposals "would create chaos in the Federal courts." ${ }^{50}$ The attorney general and the United States Sentencing Commission also opposed the D'Amato proposals. ${ }^{51}$

Majorities in both houses, however, appeared to support the D'Amato proposals when Lopez was decided, and the Court could anticipate that similar proposals would be introduced in the future

47. 140 Cong. REC. 11,183 (1994) (statement of Sen. Domenici) (noting that in their appearances before the Appropriations Committee, Justice Kennedy and Justice Souter opposed the idea of expanding the jurisdiction of the federal courts in a manner that would turn them "into police courts"). All of the reports of the hearings attribute the statement about police courts to Justice Kennedy, who picked up on Senator Hollings's use of that term. E.g., Mary Deibel, Justices Fear Effects of Crime Legislation; Federal Courts Could Become "Police Courts," S.F. EXAmINER, Mar. 4, 1994, at A9; Scripps Howard, Crime Bills Could Create Federal "Police Courts," Justices Warn Congress, ARIZ. RePUbLiC, Mar. 4, 1994, at A6; Don't Overload U.S. Courts, Justices Urge Senate Panel, UNION LEADER (Manchester, N.H.), Mar. 4, 1994, at 1 [hereinafter Don't Overload]. Justices Anthony Kennedy and David Souter expressed similar concerns in 1998. See, e.g., Steve Lash, Federal Criminal Code Shouldn't Be Widened, Justices Tell Congress, Houston CHRON., Mar. 12, 1998, at A15 (reporting the Justices' warning that more federal laws criminalizing local crime would overburden the federal courts).

48. Justice Souter stated, "I'm afraid I don't have very much optimism that federal courts can become courts of unlimited criminal jurisdiction without incapacitating the ability of those courts to do what they do well now." Don't Overload, supra note 47, at 1.

49. 140 CONG. REC. 17,234 (1994) (statement of Rep. Hughes).

50. Id. (statement of Rep. Hughes); see also Victor Williams, A Constitutional Charge and a Comparative Vision to Substantially Expand and Subject Matter Specialize the Federal Judiciary: A Preliminary Blueprint for Remodeling Our National Houses of Justice and Establishing a Separate System of Federal Criminal Courts, 37 WM. \& MARY L. REV. 535, 626 (1996) (quoting a memorandum from Judge Maryanne Trump Barry describing the efforts of Representative Hughes to defeat the D'Amato proposals using ammunition provided by the Judicial Conference).

51. Representative Hughes stated that

[t]he administration strongly opposes the Senate provisions which would largely obliterate the distinction between Federal and State criminal jurisdiction. These provisions represent a false promise of action in fighting violent crime, a promise that will not be realized given limited Federal resources. . . . [A]t best these provisions would be ineffectual; at worst, they would divert Federal resources from dealing with distinctively Federal matters in interstate crime, activities that Federal law enforcement is uniquely competent to handle.

140 CONG. REC. 17,234 (1994) (statement of Rep. Hughes) (quoting a letter from the attorney general). The Sentencing Commission concluded that the D'Amato proposals would increase the federal prison population by $383.9 \%$ over the next nine years. $I d$. 
with a good chance of enactment. ${ }^{52}$ From the Supreme Court's perspective, these proposals threatened to overload the federal courts and undermine their prestige. Although the efforts to expand federal jurisdiction over gun-related crime were not the only factor, I believe they played a significant and critical role in motivating the Court to announce the first modern judicial limitations on federal authority under the Commerce Clause.

The Chief Justice's opposition to the D'Amato proposals was a harbinger of his opinion for the Court in Lopez $^{54}$ as well as of his later opinion in Morrison. ${ }^{55}$ Writing for the Lopez majority, the Chief Justice emphasized the need to keep the traditional balance between federal and state law, "between what is truly national and what is truly local." ${ }^{, 6}$ Without setting forth any "precise formulations," the majority declined to follow a chain of inferences regarding effects on commerce that would allow Congress to regulate "all violent crime",57 as well as "activities that might lead to violent crime." 58 The Chief Justice returned to this theme in Morrison, the Court's second decision limiting the commerce power, in which it followed and extended Lo$p e z$ to hold that the civil provisions of VAWA exceeded Congress's power under the Commerce Clause (and under the Fourteenth Amendment) ${ }^{59}$ Morrison was not a firearms case,${ }^{60}$ but the domestic violence focus of VAWA (often associated with the low-status family and police courts) triggered the same institutional response that motivated the Lopez decision. Although Morrison concerned the civil rather than the criminal provisions of VAWA, the Chief Justice's opinion in Morrison emphasized that VAWA as a whole was an at-

52. See Chief Justice Addresses ABA Midyear Meeting, supra note 46, at 2 (noting that Rehnquist commented in 1992 that, although the D'Amato amendment had not passed, it "may resurface"); Rehnquist, Seen in a Glass, supra note 46, at 7 (noting that proposals such as the D'Amato proposal to federalize virtually any murder committed with a firearm "are likely to resurface").

53. This point also has been made by Barry Friedman, supra note 20, at 796 (citing my remarks at the Case Western Reserve symposium). See also Williams, supra note 50, at 631 (characterizing Lopez as a case in which the majority "took the policy, and the law, into their own hands ... to ensure that their elite federal courts would not become police courts").

54. United States v. Lopez, 514 U.S. 549 (1995).

55. United States v. Morrison, 529 U.S. 598 (2000).

56. 514 U.S. at $567-68$.

57. Id. at 564 .

58. Id.

59. Morrison, 529 U.S. at 627.

60. The complaint in Morrison alleged that the plaintiff was raped by fellow students at Virginia Polytechnic Institute. Id. at 602. 
tempt to encroach on the traditional power of the states to regulate criminal conduct under their police powers. Speaking for the Court, Rehnquist wrote,

The regulation and punishment of intrastate violence that is not directed at the instrumentalities, channels, or goods involved in interstate commerce has always been the province of the States.... Indeed, we can think of no better example of the police power, which the Founders denied the National Government and reposed in the States, than the suppression of violent crime and vindication of its victims. $^{61}$

In Lopez and Morrison, the Rehnquist-led majority served notice that the federal courts cannot be transformed into police courts. From the viewpoint of positive political theory, Lopez and Morrison reshaped Commerce Clause doctrine to protect the traditional role of the federal courts from the irreparable damage that could be inflicted by "feel-good do-something federal crime bills." ${ }^{62}$ Because gunrelated crime makes up such a large portion of the state courts' caseload, a proposal to federalize a broadly defined class of crimes involving firearms would necessarily work a radical change in the federal courts by either crowding out cases that traditionally have made up the federal courts' docket in favor of low-status police court cases or requiring an enlargement of the courts that might hamper their effectiveness and lower their prestige. ${ }^{63}$ Similar institutional interests were also present in Morrison. Although the volume of cases that could fall within the civil provisions of VAWA was limited, the subject matter was a form of extremely common criminal activity associated with the low-status family courts or criminal courts. Indeed, the Judicial Conference and the Chief Justice had publicly opposed the provisions later struck down in Morrison on the ground that they "could involve the federal courts in a whole host of domestic relations disputes." 64

61. Id. at 618 .

62. Eskridge \& Frickey, supra note 21, at 71.

63. The relatively small number of federal judgeships and the specialized nature of the federal courts are significant factors in their prestige, and a limitation on the number of judgeships is also required by the courts' pyramidal three-tier system. FED. COURTS STUDY COMM., Judicial CONFERENCE OF THE U.S., REPORT OF THE FEDERAL COURTS STUDY COMMITTEE 7-8 (1990).

64. Judith Resnik, The Programmatic Judiciary: Lobbying, Judging, and Invalidating the Violence Against Women Act, 74 S. CAL. L. REV. 269, 271 (2000) [hereinafter Resnik, Programmatic Judiciary] (quoting Rehnquist, supra note 44, at 3); see also Judith Resnik, "Naturally" Without Gender: Women, Jurisdiction, and the Federal Courts, 66 N.Y.U. L. REV. 1682, 
Pressure from gun cases was not, of course, the only factor motivating the Lopez and Morrison decisions. These cases are also part of a broader effort by the Court's majority to restrict federal power in favor of state authority, as reflected in decisions limiting federal authority to subject states to suit in federal court or commandeer state officials. ${ }^{65}$ But the Rehnquist majority's institutional concerns regarding the federalization of certain kinds of criminal cases explains the timing of the Court's first effort in half a century to limit the commerce power, the choice of the two cases in which those limitations were announced, and the limited application of those decisions. It also makes sense of the Court's failure to follow Lopez in cases that do not raise the same concerns, including civil $\operatorname{cases}^{66}$ and criminal

1687-88 (1991) (noting the Judicial Conference's concern that the legislation would "'embroil the federal courts in domestic relations disputes' and 'flood [the federal courts] with cases that have been traditionally within the province of the state courts"') (quoting Report of the Judicial Conference Ad Hoc Committee on Gender-Based Violence 1, 7 (Sept. 1991) (on file with Judith Resnick)). The Judicial Conference later dropped its opposition when the text of VAWA was amended to respond to some of the judicial objections, the leadership of the Judicial Conference committee shifted, and judges themselves were subject to lobbying. Resnik, Programmatic Judiciary, supra, at 273 \& n.17.

65. See, e.g., Bd. of Trs. of the Univ. of Ala. v. Garrett, 531 U.S. 356, 360 (2001) (holding that a provision of the Americans with Disabilities Act that authorizes private damage actions against states violates the Eleventh Amendment); Kimel v. Fla. Bd. of Regents, 528 U.S. 62, 91 (2000) (striking down a provision of the Age Discrimination in Employment Act authorizing private damage actions against a state without its consent as violative of the Eleventh Amendment); Alden v. Maine, 527 U.S. 706, 712 (1999) (holding that a provision of the Fair Labor Standards Act authorizing private damage actions against states without their consent violates the Eleventh Amendment); Fla. Prepaid Postsecondary Educ. Expense Bd. v. Coll. Sav. Bank, 527 U.S. 627, 630 (1999) (holding that the Commerce Clause, Patent Clause, and Fourteenth Amendment were insufficient to provide Congress with the authority to abrogate the states' Eleventh Amendment sovereign immunity in the Patent and Plant Variety Protection Remedy Clarification Act); Printz v. United States, 521 U.S. 898, 933-34 (1997) (holding that the obligation imposed by the Brady Act to conduct background checks on prospective handgun purchasers placed an unconstitutional obligation on state officers to execute federal law); New York v. United States, 505 U.S. 144, 177 (1992) (finding that the Low-Level Radioactive Waste Policy Act's "take title" provision, requiring states to accept ownership of waste or regulate according to the instructions of Congress, lies outside Congress's enumerated powers and is inconsistent with the Tenth Amendment). For commentary on these decisions, see, for example, Ruth Colker \& James J. Brudney, Dissing Congress, 100 MiCH. L. REV. 80, 86-87 (2001) ("We are disturbed by the Court's emerging vision in which Congress has substantially diminished powers to conduct its internal affairs or to engage in factfinding and lawmaking that the judicial branch will respect."); Vicki C. Jackson, Federalism and the Uses and Limits of Law: Printz and Principle?, 111 HARV. L. REV. 2181, 2182-83 (1998) (criticizing Printz as unstable and impractical).

66. As noted above, Morrison involved the provision of VAWA that created a private civil damage action. See supra notes 59-61 and accompanying text. Otherwise the Court has not applied Lopez to civil provisions. The Court controls its own caseload, and it apparently has not taken civil cases in which the issue was whether Congress had exceeded its jurisdiction under the Commerce Clause. It did, however, rely upon the significant constitutional issues raised in Lopez and Morrison as a justification for reading the Federal Pollution Control Act narrowly in Solid Waste Agency v. United States Army Corps of Engineers, 531 U.S. 159, 173-74 (2001). 
cases that fall within more traditional conceptions of federal criminal jurisdiction. For example, less than a week after the Lopez decision, the Court declined an opportunity to develop the themes initiated in that opinion. In United States v. Robertson, ${ }^{67}$ the Ninth Circuit had ruled that a small gold mine in Alaska lacked sufficient effect on commerce to support jurisdiction under the Racketeer Influenced and Corrupt Organizations Act (RICO) ${ }^{68}$ The Court granted certiorari on the question of the necessary degree of effect on commerce, ${ }^{69}$ but finessed this issue in a brief per curiam opinion holding that it was unnecessary to define the scope of the required effect on commerce because the gold mine was operating in interstate (as opposed to intrastate) commerce..$^{70}$

Positive political theory provides a ready explanation for the Court's quite different response to this organized crime case decided just one week after Lopez, a garden-variety gun case. Organized crime prosecutions fall within the traditional conception of the distinctive federal role in law enforcement, and RICO has never generated a large number of criminal prosecutions. ${ }^{71}$ High-profile, complex organized crime prosecutions do not have the feel of police court cases.

Two interconnected questions arise in regard to the Court's resistance to expanding federal criminal jurisdiction. First, why does the self-interest of the Supreme Court-as opposed to the lower federal courts-favor reducing the volume of federal criminal litigation? An increased number of cases might overburden the lower federal courts and reduce the prestige of judgeships on those courts, but the Supreme Court has virtually unlimited authority to determine the size of

67. 15 F.3d 862 (9th Cir. 1994).

68. Id. at 868-69.

69. See, e.g., Brief for Petitioner, at i, United States v. Robertson, 514 U.S. 669 (1995) (No. 94-251) (stating that the question presented was "[w]hether the interstate movement of goods and people in connection with the operation of a gold mine is sufficient to justify the conclusion that the activities of the gold mine affect interstate commerce within the meaning of the Racketeer Influenced and Corrupt Organizations Act").

70. Robertson, 514 U.S. at 671.

71. To be sure, commentators and lower courts have expressed concern about the civil caseloads generated by RICO, but the Supreme Court has seemed largely unmoved by these concerns, repeatedly reversing appellate decisions interpreting RICO in a fashion that would make it more difficult to bring garden-variety civil suits within RICO's ambit. The most outstanding example is Sedima, S.P.R.L. v. Imrex Co., 473 U.S. 479 (1985). Although it recognized that the court of appeals had imposed this limitation in response to the perception that civil plaintiffs were misusing RICO, the Supreme Court held that plaintiffs were not required to show a distinct racketeering injury to recover treble damages under RICO. Id. at 495-97. 
its caseload. Whatever the impact on the lower courts, the Supreme Court cannot be overburdened by the expansion of federal criminal (or civil) jurisdiction. Nonetheless, as illustrated by their reaction to the D'Amato proposals, the Justices and particularly the Chief Justice have adopted the perspective of the federal courts as a whole, rather than that of the Supreme Court.

The second question is why, in favoring its own institutional interests and prestige, the Court does not seek to expand the caseload of the federal judiciary ? $^{72}$ In general, institutional actors seek to expand their authority, or turf. ${ }^{73}$

Two possible explanations have occurred to me, one based on prestige and one on policy preferences. One form of prestige involves not extending turf, but rather remaining small and exclusive. An increased number of cases might overburden the lower federal courts and reduce the prestige of judgeships on those courts. Although the Supreme Court has virtually unlimited authority to determine the size of its docket, the Supreme Court may have adopted exclusivity over expansive jurisdiction in part because of the Chief Justice's role as the head of the Judicial Conference. In this position, the Chief Justice presents to Congress the views of the federal judiciary as a whole, rather than the views of the Supreme Court. ${ }^{74}$ Although the Chief Justice presides over the Judicial Conference, judges from the lower federal courts otherwise comprise the Conference. ${ }^{75}$ Thus the experiences and preferences of influential members of the lower federal courts heavily influence the Chief Justice's institutional perspective. ${ }^{76}$

72. Professor Vicki Jackson suggested this provocative question at a Georgetown workshop. Judith Resnik also notes that as a rational actor, the federal judiciary might seek expanded jurisdiction to have "increases in judicial person-power." Resnik, supra note 26, at 96768.

73. See, e.g., William A. Niskanen, JR., Bureaucracy And Representative GOVERNMENT 38-41 (1971) (asserting that regulators prefer to expand the number of transactions subject to their regulation); $c f$. DAVID C. KING, TURF WARS: HOW CONGRESSIONAL COMMITTEES CLAIM JURISDICTION 6-9 (1997) (describing committee efforts to extend jurisdiction).

74. The Chief Justice is required by 28 U.S.C. $\S 331$ (1994) to "submit to Congress an annual report of the proceedings of the Judicial Conference and its recommendations for legislation." During Warren Burger's term as Chief Justice, he adopted the practice, continued by Chief Justice Rehnquist, of making an annual "State of the Judiciary" address. Resnik, Programmatic Judiciary, supra note 64, at 270 \& n.3.

75. The Judicial Conference consists of the chief judge of each of the twelve judicial circuits, the chief judge of the Court of International Trade, and a district judge from each judicial circuit. 28 U.S.C. $\$ 331$.

76. Note, however, that in other respects the Chief Justice exercises a great deal of influence within the Judicial Conference. The Chief Justice selects the members of the Judicial Con- 
To the extent that the Chief Justice played a dominant role in Lopez and Morrison - in which he wrote both opinions - his role as head of the Judicial Conference might have been quite significant.

Perhaps more important, the institutional perspective of each branch coexists with individuals' policy preferences. As manifested in many other cases, the Justices who made up the majority in Lopez and Morrison prefer restricting the size and influence of the federal government in favor of the states. ${ }^{77}$ Some or all of these Justices also may have little sympathy for the groups seeking redress under VAWA ${ }^{78}$ or they may oppose federal regulation of firearms. ${ }^{79}$ Individual Justices' policy preferences would likely make them receptive to concerns of overburdening the lower courts and diluting their elite role.

Positive political theory also raises the question whether there should be additional restraints on the courts' self-interested actions. The Chief Justice's opposition to the D'Amato proposals was not an isolated occurrence. As Judith Resnik demonstrates, the Judicial Conference has become increasingly involved in lobbying Congress in favor of institutional recommendations about the scope of the federal courts' jurisdiction. ${ }^{80}$ These institutional recommendations inevitably involve not only caseload considerations, but also policy judgments about competing groups that seek access to and the protection of the federal courts. ${ }^{81}$ Resnik argues that the norms advocated by the Judicial Conference become background assumptions that can shape the adjudication of cases, determining the rights of the groups in ques-

ference Committees that propose policies to the governing board. Resnik, Programmatic Judiciary, supra note 64, at 285.

77. See supra note 65 and accompanying text.

78. Rehnquist is not known as a supporter of women's issues. Before joining the Court, he opposed the proposed Equal Rights Amendment to the Constitution and suggested that the women's movement includes "a virtually fanatical desire to obscure not only legal differentiation between men and women, but insofar as possible, physical distinctions between the sexes." Donald E. Boles, Mr. Justice ReHnQuist, Judicial ACTIVIST: The EARly YeARs 6-7 (1987) (quoting Rehnquist).

79. Justice Thomas's opinion in Printz v. United States, 521 U.S. 889, 936-39 (Thomas, J., concurring), suggests that he is receptive to a robust interpretation of the Second Amendment that would limit the government's authority to regulate firearms. See also Staples v. United States, 511 U.S. 600, 611 (1994) (Thomas, J.) (rejecting the government's assertion that handguns should be likened to hand grenades, and observing that "despite their potential for harm, guns generally can be owned in perfect innocence").

80. Resnik, Programmatic Judiciary, supra note 64, at 278-82.

81. Id. at 287-88. 
tion. ${ }^{82}$ Positive political theory reinforces Resnik's observations about the motives of the Judicial Conference and lends weight to her call for restricting the judiciary's role in lobbying regarding the scope of federal jurisdiction.

Separation of powers concerns, on the other hand, support selfinterested judicial rulings (and perhaps even judicial lobbying), particularly when the political branches adopt policies that can seriously damage the courts and the public interest. William Stuntz argues powerfully that the institutional roles of both prosecutors and legislators drive them to continually expand the criminal law, increasing the number and breadth of offenses as well as the penalties. ${ }^{83}$ Action is more politically popular than inaction, and at the federal level most anticrime legislation creates new federal offenses or provides new federal resources to prosecute federal offenses. This institutional design, Stuntz suggests, leaves the courts with relatively little ability to check the one-way ratchet wielded by the other branches. ${ }^{84}$ Other research suggests that the media's focus on crime also creates strong public and political pressures in favor of ever-expanding criminal liability. ${ }^{85}$

If these accounts of the political economy of criminal law are correct, they may argue for allowing the courts some leeway to enter the political arena. They certainly provide a reason to allow courts to consider institutional self-interest as a factor in their constitutional analysis. Indeed, the fundamental insight of positive political theorythat each branch acts in ways consistent with its institutional selfinterest-is a fundamental tenet of the theory of separation of powers as espoused by the Founders. As Federalist No. 51 explains, the purpose of the division of powers among the executive, legislative, and judicial branches is for the branches to "be the means of keeping each

82. Id. at $288-89$; cf. generally Robel, supra note 43 (identifying the federal judiciary's institutional interests and suggesting that it should not lobby Congress about jurisdictional provisions).

83. William J. Stuntz, The Pathological Politics of Criminal Law, 100 MicH. L. REV. (forthcoming 2001) (manuscript at 528-39, on file with the Duke Law Journal).

84. Id. (manuscript at 529).

85. See, e.g., Sara Sun Beale, What's Law Got To Do With It: The Political, Social, Psychological and Other Non-Legal Factors Influencing the Development of (Federal) Criminal Law, 1 BUFF. CRIM. L. REV. 23, 47-51 (1997) (describing research identifying direct and indirect means by which crime and violence in the media may influence public opinion); Sara Sun Beale, Economic Pressures and Internal Structure Shape the U.S. Media's Treatment of Crime: Do They Also Shape U.S. Criminal Justice Policy? 1 (Nov. 2001) (unpublished manuscript, on file with the Duke Law Journal) (arguing that media coverage has had a significant impact on public opinion and criminal justice policy). 
other in their proper places." ${ }^{\prime 86}$ The constitutional structure was premised upon the idea that each branch would be self-interested: "Ambition must be made to counteract ambition." proper for the judiciary, which bears the burden of Congress's extension of federal jurisdiction to gun cases, to bring these values into play in its interpretation of the Commerce Clause, providing some counterweight to the political branches, which inevitably will press, over time, for enlarged criminal jurisdiction.

\section{B. Executive Initiatives}

The same expansive pressures also operate at the administrative level under the existing federal gun statutes. In conjunction with local authorities, the United States attorney in Richmond, Virginia, developed a program called Project Exile. ${ }^{88}$ Beginning in early 1997, Project Exile targeted gun violence in Richmond by funneling all gun arrests made by state and local authorities into federal court, where, if at all possible, defendants were prosecuted under federal firearms statutes. ${ }^{89}$ This was, of course, a radical departure from the ordinary practice, in which street crime is the general province of state and local police and prosecutors. As a result of Exile, gun homicides dropped substantially in Richmond, and Exile became one of the most highly publicized federal anticrime initiatives of the Clinton era. $^{90}$

Project Exile gun prosecutions are now being handled by prosecutors detailed from state and local offices. ${ }^{91}$ Thus, although the United States attorney initially believed that the project (which has

\footnotetext{
86. The Federalist No. 51, at 320 (James Madison) (Clinton Rossiter ed., 1961).

87. Id. at 322 .

88. Daniel C. Richman, "Project Exile" and the Allocation of Federal Law Enforcement Authority, 43 ARIZ. L. REV. 369, 370 (2001).

89. Id. at 370. As Richman explains, federal authorities relied principally upon federal statutes that criminalize the possession of a firearm by anyone previously convicted of a felony or crime of domestic violence, 18 U.S.C. $\$ 922(\mathrm{~g})(2000)$, and the use of a firearm in connection with drug trafficking, 18 U.S.C. $§ 924(c)$. Richman, supra note 88 , at $370 \&$ nn.4-5.

90. Richman, supra note 88, at 370 (quoting President Clinton's claim that the number of gun murders declined by forty-one percent). Richman analyzes the political support for Project Exile, which has been strongest among Republicans, conservatives, and supporters of the National Rifle Association, and contrasts Exile with competing programs that received greater support from Democrats and those who favor more aggressive gun control measures. See id. at 371, 406-07 (noting that many conservatives rallied around Project Exile while some Democrats championed an "activist regulatory program").

91. See id. at 380 (noting that two years after the initiation of Project Exile it required more limited personnel resources because cases were staffed in part by prosecutors "detailed from state and local offices").
} 
generated more than 400 cases) would be a substantial burden on her office, ${ }^{92}$ a later review reported that the personnel resources required were "relatively limited" because state prosecutors had been designated to handle these federal cases. ${ }^{93}$ The practice of cross-designating state prosecutors to bring federal prosecutions is now well established, and it is one of the means that can be used to cope with an expanded caseload of gun-related crimes. Indeed, Senator D'Amato argued that state prosecutors could be designated to bring the resulting federal prosecutions if his amendment making all gun crimes federal offenses were enacted. ${ }^{94}$

Project Exile demonstrates that efforts to expand federal jurisdiction over gun offenses can alter what federal jurisdiction means in practice. In gun cases, federal jurisdiction may routinely mean that a state rather than a federal prosecutor will exercise charging and bargaining discretion, and will represent the United States in court. Statutory authority clearly allows individuals to act as federal prosecutors in particular cases. ${ }^{95}$ But programs like Project Exile may transform case-by-case cross-designation into a semipermanent, wholesale incorporation of a group of junior varsity federal prosecutors. These prosecutors will not undergo the same selection process as "real" federal prosecutors, ${ }^{96}$ and they will not have the same training. ${ }^{97}$ More-

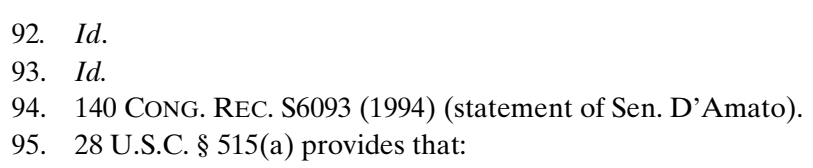

[A]ny attorney specially appointed by the Attorney General under law, may, when specifically directed by the Attorney General, conduct any kind of legal proceeding, civil or criminal, including grand jury proceedings and proceedings before committing magistrates, which United States attorneys are authorized by law to conduct, whether or not he is a resident of the district in which the proceeding is brought.

28 U.S.C. $\$ 515$ (a) (1994). Subsection (b) provides that "[e]ach attorney specially retained under authority of the Department of Justice shall be commissioned as special assistant to the Attorney General or special attorney." Id. $\S 515(\mathrm{~b})$.

96. For a variety of reasons, the federal hiring process is generally more selective than the state process. Two important factors are compensation and workload. Federal pay scales generally exceed those for state prosecutors, and federal prosecutors generally are responsible for a smaller number of cases. Frank O. Bowman, III \& Michael Heise, Quiet Rebellion? Explaining Nearly a Decade of Declining Federal Drug Sentences, 86 IowA L. REV. 1043, 1127-28 (2001) ("The imperative to move an omnipresent backlog of cases through the system, so common in state prosecutors' offices, is rarely a consideration among United States Attorney's Offices.") (footnotes omitted).

97. Federal prosecutors generally have more extensive opportunities for training than their state counterparts. The Department of Justice's Executive Office for United States Attorneys operates the National Advocacy Center (NAC) to train 10,000 federal and state prosecutors annually. U.S. Dep't of Justice, NAC Facts, USDOJ.gov, at http://www.usdoj.gov/usao/eousa/ ole/nacfacts.html (last visited Jan. 20, 2002) (on file with the Duke Law Journal) (stating that 
over, virtually all state prosecutors work in offices headed by an elected district attorney, and state prosecutors' offices are typically more politicized than their federal counterparts. ${ }^{98}$ The federal system is quite decentralized, with most prosecutorial decisions controlled by the United States attorney in each federal judicial district, but all federal prosecutors receive a degree of centralized control, training, and oversight from the Department of Justice, and they benefit from centralized legal and policy resources. ${ }^{99}$ The present federal system keeps politics in check and strikes a careful balance between uniformity and diversity. The centralizing effects of the authority of the attorney general and the Department of Justice are balanced by the authority conferred on the presidentially appointed United States attorneys who are responsible for federal law enforcement in their judicial dis-

the facility was built to "train federal, state, and local prosecutors" and that "more than 10,000 [were] expected to train annually"). Although courses for state prosecutors are presented at NAC by the National District Attorneys Association, a review of the curriculum indicates that the bulk of the courses are aimed at federal attorneys and members of their staffs. See U.S. Dep't of Justice, OLE Course Schedule, USDOJ.gov, at http://www.usdoj.gov/usao/eousa/ole/ calendar.html (last visited Jan. 20, 2002) (on file with the Duke Law Journal) (listing the courses taught at NAC during fiscal year 2002). Given the relative numbers of federal and state prosecutors, the average federal prosecutor is far more likely to attend courses at NAC than the average state prosecutor.

98. See Stuntz, supra note 83 (manuscript at 533 n.117) (citing a government report concluding that more than ninety-five percent of local district attorneys are elected).

In contrast, federal prosecutors report to supervisors who are appointed, rather than elected. Most federal prosecutions are conducted by assistant United States attorneys, who are appointed by and report to the United States attorney for the district in question. See JAMES EISENSTEIN, COUNSEL FOR THE UNITED STATES: U.S. ATTORNEYS IN THE POLITICAL AND LEGAL SYSTEMS 12 (1978) (noting that in practice United States attorneys select their own assistants, even though the attorney general has the formal authority to hire and remove assistants). Some federal prosecutions (e.g., tax cases) are conducted by attorneys from a division of the Department of Justice. See, e.g., U.S. DeP'T OF Justice, United STATES ATtorneys' MANUAL II 6-4.200, USDOJ.gov, at $\mathrm{http}: / /$ www.usdoj.gov/usao/eousa/foia_reading_room/usam/ title6/4mtax.html (last visited Feb. 8, 2002) (on file with the Duke Law Journal) (stating that with few exceptions, the "Assistant Attorney General, Tax Division, has responsibility for all criminal proceedings arising under the internal revenue laws"); id. II 6-2.000 (noting the requirement of Tax Division approval for the initiation of grand jury proceedings, indictments, etc.). Each such division is headed by an assistant attorney general who is a presidential appointee subject to Senate confirmation. See 28 U.S.C. $\$ 506$ (1994) (providing that the president may appoint assistant attorneys general with the advice and consent of the Senate). Ultimately all federal prosecutors are subject to the supervision of the attorney general, see EISENSTEIN, supra, at 12 (noting that "[t]he ability of the Attorney General to hire and fire his field office supervisors rests on his influence with the President and [on] his willingness to exert it"), who is also nominated by the president and confirmed by the Senate. 28 U.S.C. $\S 503$ (providing that the president shall appoint the attorney general with the advice and consent of the Senate).

99. For example, the United States Attorneys' Manual and related publications provide well-researched guidance on substantive and procedural law. 
tricts. ${ }^{100}$ When cross-designated state prosecutors are given responsibility for a part of the federal criminal docket, do they exercise their authority in the same fashion as "real" federal prosecutors? How does this affect the balance between uniformity and diversity? Does it inject a greater political emphasis in prosecutorial decisions? Given the enormous discretion wielded by federal prosecutors (a point discussed in greater detail below), ${ }^{101}$ a good deal rides on the decision to consistently use such hybrid federal-state prosecutors.

Project Exile has had a different effect on the courts. Prosecutorial discretion and the option of cross-designating state prosecutors give the Justice Department and federal prosecutors the means to deal with legislative efforts to expand federal jurisdiction to reach gun-related crime. ${ }^{102}$ If federal prosecutors lack sufficient resources to prosecute these cases, they may choose not to bring the prosecutions or may cross-designate state prosecutors to present the cases in federal court. In contrast to prosecutors, the federal courts have no capacity to cross-designate state judges, and they have no discretion to dismiss criminal prosecutions that exceed their resources. ${ }^{103}$ Thus the federal courts are more likely than federal prosecutors to feel the pinch of legislation extending federal criminal jurisdiction and may have a greater stake in reading such statutes narrowly or construing the Commerce Clause in a narrow fashion. ${ }^{104}$ It is unsurprising that

100. See EISENSTEIN, supra note 98, at 54-125 (discussing the dynamic balance of power among the United States attorneys, the attorney general, and the Department of Justice); see also Daniel C. Richman, Federal Criminal Law, Congressional Delegation, and Enforcement Discretion, 46 UCLA L. REV. 757, 789-810 (1999) (discussing how Congress constrains the discretion of federal prosecutors).

101. See infra Part II.B (describing prosecutors' decisions not to charge defendants with \$ 924(c) violations).

102. Moreover, at least in the case of proposals to expand Project Exile, specific funds may be earmarked for additional federal prosecutors. See Richman, supra note 88, at 384-85, 393, 395 (describing various proposals that would provide funding for additional federal prosecutors for firearms cases).

103. Cf. United States v. Ucciferri, 960 F.2d 953, 954-55 (11th Cir. 1992) (noting that the systematic movement of state criminal cases to federal court may be a source of concern to federal courts, but concluding that, in light of the "executive's [discretionary power] to initiate criminal proceedings," the federal courts have no authority to dismiss cases even in the absence of any discernible federal interests or ties).

104. It should be noted, however, that eventually the executive branch bears the cost of the incarceration of all federal offenders, and this expense has been growing very rapidly. See Sara Sun Beale, Reporter's Draft for the Working Group on Principles to Use When Considering the Federalization of Criminal Law, 46 HASTINGS L.J. 1277, 1289-92 (1995) (describing the growth in the federal prison population and the budget for the Bureau of Prisons, and noting that federal expenditures for law enforcement have grown more rapidly than state expenditures). Indeed, federalization of crimes traditionally prosecuted by the states "[can be viewed] as a form of in-kind fiscal relief for state and local government, which do not have to pay for the investiga- 
the chief judge of the United States District Court in Richmond has complained that Project Exile has turned the federal district court into a "a minor-grade police court." 105 This objection underlines the point made in the previous Section about the federal courts' selfinterested behavior.

Pressure also may be building on another traditional boundary, the boundary between legislative and executive authority in the decision to bring federal criminal prosecutions. Project Exile demonstrates that existing federal firearms provisions are already broad enough, if used aggressively, to flood the federal courts with cases that traditionally have been heard in state courts. At present, each United States attorney's office decides how many gun cases to bring. Congress traditionally has accorded federal prosecutors virtually unregulated discretion to determine whether and when to bring prosecutions under the existing federal criminal statutes. ${ }^{106}$ Prosecutors use their discretion to tailor caseloads to resources, accommodate local circumstances, set priorities, and take account of the equities and evidentiary strengths of individual cases. Although prosecutors exercise much of their discretion in a decentralized fashion, the attorney general establishes some priorities at a national level. At various points in time Attorneys General have made white collar and organized crime national priorities, ${ }^{107}$ and during the early 1990s, Attorney General Richard Thornburg announced Operation Triggerlock, an effort to use federal laws to prosecute the most serious violent offenders. ${ }^{108} \mathrm{Al}-$ though these prosecutorial priorities have been set by the attorney

tive, prosecutorial, judicial, and correctional resources that are now devoted to these cases." Id. at 1291 . This fiscal relief occurs, on a deferred basis, when the state conducts the investigation and provides the prosecutor, but the federal government provides the judicial and correctional resources.

105. John S. Baker, State Police Powers and the Federalization of Local Crime, 72 TEMPLE L. REV. 673, 687 (1999) (quoting a letter from the chief judge to Chief Justice Rehnquist); see also United States v. Jones, 36 F. Supp. 2d 304, 310-12 (E.D. Va. 1999) (criticizing Project Exile for subjecting African-American defendants to trial before juries with a low percentage of African Americans and also for violating principles of federalism). Jones is discussed in Richman, supra note 88 , at 382-83, 400 n.205.

106. For a discussion of the factors that traditionally govern the exercise of prosecutorial discretion in the federal system, see Norman Abrams \& SARA Sun Beale, Federal CRIMINAL LAW AND ITS ENFORCEMENT 317-31, 642-53 (3d ed. 2000), and Richman, supra note 100 , at $789-805$.

107. For a brief discussion of national priorities, see ABRAMS \& BEALE, supra note 106, at 104-12.

108. See Text of Triggerlock Implementation Memo, DOJ ALERT, vol. 1, No. 1, at 17 (July 1991) (stating that the objective of Project Triggerlock was to deter "criminals from possessing firearms"). 
general, the United States attorneys, and the heads of other units within the Department of Justice, those priorities were subject to a continuing dialogue with Congress as it pursued its oversight responsibilities and considered the Department's appropriations.

Since Project Exile, however, Congress has proposed various nationwide mandates based on the Exile model. ${ }^{109}$ It would be a highly significant change if Congress were to mandate a national program requiring prosecutors to bring gun cases in the federal courts, instead of simply providing federal prosecutors with the tools to bring such cases in their discretion. Some of the post-Exile legislative activity takes a step in that direction. For example, the Criminal Use of Firearms by Felons (CUFF) Program, which the Senate passed in 1999 with the support of Republicans (including then-Senator John Ashcroft) provided that in twenty-five high-crime jurisdictions the attorney general and the secretary of the treasury were to provide for the establishment of Exile-style agreements, in which state and local law enforcement officials would refer firearms prosecutions to the Bureau of Alcohol, Tobacco, and Firearms and the United States attorney. ${ }^{110}$ CUFF also required that the United States attorney in each district designate not less than one assistant to prosecute these cases, and most importantly, that each person referred to the United States Attorney's Office under these programs be charged with a violation of the most serious federal firearms offense committed. ${ }^{111}$

The recent experience with Project Exile demonstrates that the efforts to impose harsh federal penalties on gun criminals may have a major effect on federal prosecutorial practices by weakening the traditional assumption that federal prosecutors will prosecute federal crimes, and by giving Congress an incentive to regulate prosecutorial practices more closely.

\section{The Boundary DEFINING Gun OFFENSES-PRESSURE AT THE MARGINS, EVASION IN SOME CORE CASES}

Another boundary, the line defining the elements of the offenses in question, also has been affected by the pressure to increase the punishments for gun crimes. The principal federal firearms enhancement statute, 18 U.S.C. $\S 924(c)$, which has become the most fre-

109. Richman, supra note 88, at 386-90 (detailing legislators' reactions to Exile and the resulting proposals).

110. S. 254, 106th Cong. $\$ 803$ (1999).

111. Richman, supra note 88 , at $387-88$ \& nn. 132-35. 
quently prosecuted federal firearms statute, presents the clearest evidence of this trend. ${ }^{112}$ In contrast to the pressure on the federal-state boundary, which originates with Congress, the pressure on an offense's definition comes primarily from prosecutors (though the courts and Congress play roles in response). Congress sets a boundary when it defines the elements of a federal offense. Federal prosecutors then select cases that arguably fall within the statutory language and prosecute them under the statute in question. Inevitably, questions arise about the breadth of particular statutory terms, and individual prosecutors (and the Department of Justice) have to determine how aggressively to interpret these terms. In this Part, I show that federal prosecutors have argued in favor of very expansive-and in some cases quite extreme-interpretations of the elements of $\S 924(\mathrm{c})$, and that this prosecutorial behavior is a response to the opportunity to impose higher penalties in additional cases that do not implicate the core concerns of $\S 924(\mathrm{c})$.

The volume of litigation concerning the definition of $\S 924(c)$ has been extraordinary. The Supreme Court has decided eight cases involving different facets of the construction of $\S 924$ (c) since its passage in $1968,{ }^{113}$ and many other issues have been litigated extensively in the lower courts. This unusual volume of litigation results, at least in part, from especially aggressive efforts by federal prosecutors to impose harsher penalties in cases at-or beyond - the outer limits of

112. Patrick Walker \& Pragati Patrick, Trends in Firearms Cases from Fiscal Year 1989 Through 1998, and the Workload Implications for the U.S. District Courts, USCOURTS.gov, at http://www.uscourts.gov/firearms/firearms00.html (last visited Jan. 19, 2002) (on file with the Duke Law Journal) (writing on behalf of the Administrative Office of the U.S. Courts, and noting that $\S 924$ (c) was the most frequently prosecuted firearms offense in 1998).

113. Castillo v. United States, 530 U.S. 120, 121 (2000) (concluding that the subsection that imposes a higher penalty on the use of a "machinegun" than on other firearms states an element of a separate aggravated crime under $\S 924(\mathrm{c})$ ); Muscarello v. United States, 524 U.S. 125, $126-$ 27 (1998) (construing the term "carry" under § 924(c) to include firearms conveyed in a vehicle); United States v. Gonzales, 520 U.S. 1, 6-11 (1997) (construing "any other term of imprisonment" to require sentences under $\S 924$ (c) to be served consecutively to state as well as federal sentences); Bailey v. United States, 516 U.S. 137, 150 (1995) (construing "uses" to require active employment); Smith v. United States, 508 U.S. 223, 225 (1993) (construing the term "uses" to include the situation in which a defendant trades a firearm for drugs); Deal v. United States, 508 U.S. 129, 130-31 (1993) (construing the phrase "second or subsequent conviction" to mean "an additional finding of guilt rendered at any time'"); Busic v. United States, 446 U.S. 398, 399-401 (1980) (holding that a sentence for a $\S 924$ (c) violation may not be imposed in a prosecution for assault under 18 U.S.C. $\$ 111$, which provides for an enhanced sentence when a defendant "uses" a deadly weapon); Simpson v. United States, 435 U.S. 6, 16 (1978) (holding that a sentence for a $\$ 924$ (c) violation may not be imposed in a prosecution for bank robbery under 18 U.S.C. $\$ 2113$, which provides for an enhanced sentence when robbery is committed "by use of a dangerous weapon or device"). 
the statute, as defined by the statutory terms enacted by Congress. The higher penalties that were intended to deter would-be criminals have given prosecutors a strong incentive to press the boundaries of the statute outward to capture more cases.

This Part describes the litigation in which the government has pressed to expand the coverage of $\S 924(\mathrm{c})$, and then explores two other trends that seem on their face to conflict with the theory that the government is pressing the outward boundaries defining this offense. These seemingly conflicting trends reflect an underutilization of the statute, namely the frequent discretionary dismissal of charges, and the refusal of prosecutors to charge under $\S 924$ (c) (despite its mandatory terms) in a significant proportion of the cases that clearly fall within its ambit. The end result of the effort to impose harsh federal penalties on gun crimes has been the opposite of that intended.

Part I described how the effort to expand federal jurisdictionand thus harsh federal penalties-to more gun cases resulted in decisions announcing a curtailment of legislative authority under the Commerce Clause. This Part explains how a similar unintended backlash has undermined the legislative goal. Although the class of cases in which the penalties may be imposed has been expanded by prosecutorial efforts to convince the courts to give the statute an unusually broad reading, Congress's efforts to ratchet up the penalties and make them mandatory has created a situation in which it appears that the penalties are now imposed in only a minority of the cases to which they apply.

A. Pressing the Definitional Limits of the Elements of 18 U.S.C. $\S 924(c)$

Federal and state firearms enhancement statutes impose additional penalties on offenders who employ firearms in the commission of certain offenses. These enhancement statutes reflect "the common-sense view of many policymakers - and much of the public - that [longer sentences] will necessarily reduce gun crime, either through deterrence of new offenses or incapacitation of dangerous offenders." 114

114. Hofer, supra note 1, at 45. For a recent statement on the floor of Congress expressing these assumptions, see 144 CONG. REC. S12670 (1998) (statement of Sen. DeWine) (noting that "the purpose of this 'use or carry' provision is twofold: to punish criminals who use guns, and to be a deterrent to would-be criminals not to use a gun"). 
In seeking these goals, Congress repeatedly has ratcheted up the penalties under § 924(c). ${ }^{115}$ As originally enacted in 1968, § 924(c) was punishable by sentence of one to ten years in addition to the penalty for the underlying offense. ${ }^{116}$ In 1984 , the statute was amended to require a minimum sentence of five years, to be served consecutively to the underlying offense if a defendant used or carried a firearm in a crime of violence. ${ }^{117}$ Later amendments added drug trafficking to the predicate offenses and increased the penalties. ${ }^{118}$ A mandatory consecutive term of thirty years was provided for using or carrying more dangerous firearms (such as machine guns and assault weapons), and a mandatory sentence of twenty-five years to life was provided for offenders with prior convictions. ${ }^{119}$ Congress in 1998 increased the penalties for "brandishing" or "discharging" a firearm in the course of a predicate felony and for repeat offenders and those who use especially dangerous firearms. ${ }^{120}$

115. For a more detailed discussion of the legislative history of $\$ 924(\mathrm{c})$, see Kristin Whiting, The Aftermath of Bailey v. United States: Should Possession Replace Carry and Use Under 18 U.S.C. \& 924(c)(1)?, 5 J.L. \& POL'Y 679, 682-91 (1997). See also David T. Hardy, The Firearms Owners' Protection Act: A Historical and Legal Perspective, 17 CuMB. L. REV. 585, 589-604 (1987) (reviewing the legislative history of firearms provisions through 1986).

116. Although $\S 924$ (c) was enacted as part of the Omnibus Crime Control and Safe Streets Act of 1968, Pub. L. No. 90-351, § 902, 82 Stat. 197, 233, the pertinent provisions were added later that year in an amendment included in the Gun Control Act of 1968, Pub. L. No. 90-618, $\S 102,82$ Stat. $1213,1223-24$.

117. Act of Oct. 12, 1984, Pub. L. No. 98-473, § 1005(a), 98 Stat. 2028, 2138.

118. See Firearms Owners' Protection Act, Pub. L. No. 99-308, § 104(a), 100 Stat. 449, 457 (1986) (adding drug trafficking to predicate offenses under $\S 924(c)$ ).

119. 18 U.S.C. $§ 924$ (c)(1)(B)(ii) (2000) (stating that anyone committing a crime while carrying a machine gun will be sentenced to an additional thirty years); $i d$. $\$ 924(\mathrm{c})(1)(\mathrm{C})(\mathrm{i})$ (increasing the additional sentence for a second or subsequent offense to twenty-five years).

120. Act of Nov. 13, 1998, Pub. L. No. 105-386, § 1, 112 Stat. 3469, 3469-70. Section 924(c)(1) now provides:

(A) Except to the extent that a greater minimum sentence is otherwise provided by this subsection or by any other provision of law, any person who, during and in relation to any crime of violence or drug trafficking crime (including a crime of violence or drug trafficking crime that provides for an enhanced punishment if committed by the use of a deadly or dangerous weapon or device) for which the person may be prosecuted in a court of the United States, uses or carries a firearm, or who, in furtherance of any such crime, possesses a firearm, shall, in addition to the punishment provided for such crime of violence or drug trafficking crime-

(i) be sentenced to a term of imprisonment of not less than 5 years;

(ii) if the firearm is brandished, be sentenced to a term of imprisonment of not less than 7 years; and

(iii) if the firearm is discharged, be sentenced to a term of imprisonment of not less than 10 years.

(B) If the firearm possessed by a person convicted of a violation of this subsection- 
Three aspects of $\S 924(c)$ are significant: the penalties are harsh, they are mandatory upon conviction, and they must be served consecutively to all other sentences. For a first offense under $\S 924$ (c)(1), the mandatory minimum sentence for "use" of a firearm ranges from five to thirty years (depending upon the type of firearm involved) if the firearm is neither brandished nor discharged. ${ }^{121}$ The penalties for a "second or subsequent conviction" are even more severe: a mandatory minimum consecutive term of twenty-five years of imprisonment, regardless of the type of firearm involved. ${ }^{122}$ These mandatory penalties are designed to be severe, and they now exceed the penalties imposed for many of the most serious federal and state offenses. For example, the median sentence for rape or robbery in state courts is five years, and the median state sentence for aggravated assault is twentythree months. ${ }^{123}$ Under the Federal Sentencing Guidelines, the average base offense levels for bank robbery, kidnapping, and assault with intent to kill are all less than five years, the lowest sentence possible

(i) is a short-barreled rifle, short-barreled shotgun, or semiautomatic assault weapon, the person shall be sentenced to a term of imprisonment of not less than 10 years; or

(ii) is a machinegun or a destructive device, or is equipped with a firearm silencer or firearm muffler, the person shall be sentenced to a term of imprisonment of not less than 30 years.

(C) In the case of a second or subsequent conviction under this subsection, the person shall-

(i) be sentenced to a term of imprisonment of not less than 25 years; and

(ii) if the firearm involved is a machinegun or a destructive device, or is equipped with a firearm silencer or firearm muffler, be sentenced to imprisonment for life.

(D) Notwithstanding any other provision of law-

(i) a court shall not place on probation any person convicted of a violation of this subsection; and

(ii) no term of imprisonment imposed on a person under this subsection shall run concurrently with any other term of imprisonment imposed on the person, including any term of imprisonment imposed for the crime of violence or drug trafficking crime during which the firearm was used, carried, or possessed.

18 U.S.C. $\$ 924(c)(1)(2000)$.

121. 18 U.S.C. $\S 924(c)(1)(A),(B)$. The minimum penalty increases to seven years if the weapon is brandished, and to ten years if the weapon is discharged. Id. § 924(c)(1)(A)(ii), (iii).

122. Id. § 924(c)(1)(C)(i).

123. Bureau of Justice Statistics, U.S. DeP'T Of Justice, Sourcebook of CRiminal JUSTICE STATISTICS 458 tbl.5.44 (2000), available at http://www.albany.edu/sourcebook/1995/ pdf/section5.pdf (on file with the Duke Law Journal) (reporting data from 1996). 
under $\S 924(\mathrm{c}) .^{124}$ Although the Sentencing Guidelines themselves provide for enhancements when a firearm is involved in the commission of an offense, sentences are substantially less under the Guidelines enhancements than under $\S 924(\mathrm{c}) \cdot{ }^{125}$ Furthermore, because sentences under $\S 924(c)(1)$ are mandatory and consecutive to all other sentences, a defendant will be imprisoned significantly longer if he is charged and convicted under the statute.

Thus, §924(c) now operates as a kind of super-enhancement statute. Although Congress sought to alter the behavior of would-be criminals, the provision's effects on the behavior of the prosecution and defense are more interesting.

In civil litigation, a damage remedy that is significantly greater than remedies for similar causes of action does alter litigants' behavior. The civil provision of RICO_-which provides for treble damages plus attorneys fees ${ }^{126}$ - presents a useful comparison. Many gardenvariety civil causes of action also can support civil RICO claims, ${ }^{127}$ and

\footnotetext{
124. Under the Guidelines, the base offense sentences for the following offenses are: robbery 33-41 months;

U.S. SENTENCING GUIDELINES MANUAL §§ 2A1.3, 2A2.1, 2A4.1, 2B3.1 (2001) (using the table in chapter 5.A of the Guidelines to convert offense levels to the corresponding length of sentence that can be imposed). These offense levels are adjusted upwards if a firearm is displayed, brandished, discharged, or otherwise used. See supra notes 114-20 and accompanying text; $c f$. 144 CONG. REC. H10330 (1998) (statement of Rep. Scott) (opposing the 1998 increase in penalties in 18 U.S.C. $\$ 924$ (c) on the ground that the mandatory ten-year minimum sentence for a defendant who possessed both crack and a handgun would be more than the penalty for the more serious offenses of rape, aggravated assault, or kidnapping).

125. One study by a researcher from the Sentencing Commission finds that the sentence imposed by $\S 924$ (c) (as amended in 1998) exceeds the current average sentence under the Guidelines by thirty-one to ninety months for each representative group of offenses. Hofer, supra note 1 , at $67 \&$ tbl.2. The largest difference is for aggravated assault in which a firearm was discharged, where the average sentence under the Guidelines in fiscal year 1998 was sixty-nine months, and the sentence under $\S 924$ (c) as amended would be 159 months. Id. Another study by researchers from the Administrative Office of the U.S. Courts also finds that the average enhancement under the statute between 1992 and 1998 far exceeded the average imposed under the Guidelines. Bureau of Justice Statistics, U.S. Dep't of Justice, Special Report, Federal Firearm Offenders, 1992-98, with Preliminary Data for 1999, at 9 tbl.8 (2000), available at http:// www.ojp.usdoj.gov/bjs/abstract/ffo98.htm [hereinafter Bureau of Justice Statistics] (on file with the Duke Law Journal) (noting that the average firearm enhancement from 1992 to 1998 varied from 81 to 109.7 months under the statute and from 12.7 to 17.4 months under the Guidelines).

126. 18 U.S.C. $\$ 1964$ (c) (2000).

127. See Gerard E. Lynch, A Conceptual, Practical, and Political Guide to RICO Reform, 43 VAND. L. REV. 769, 793-94 (1990) (reporting that few civil RICO lawsuits concern organized crime and also noting that allegations of business or securities fraud account for the "vast bulk" 
professional responsibility requires plaintiffs' counsel to state civil RICO allegations where they can be made in good faith. ${ }^{128}$ Indeed, one authority on RICO suggests that "it is virtually malpractice not to add a RICO cause of action to a complaint" wherever technically possible. ${ }^{129}$ Once the private bar understood the potential of civil RICO, plaintiffs' lawyers exploited RICO in a wide variety of cases ranging far afield from the organized crime cases Congress contemplated. ${ }^{130}$ Plaintiffs' counsel clearly pushed the envelope on various elements of this cause of action in an attempt to obtain triple recoveries plus litigation costs. Since the elements of criminal and civil RICO are the same, it is not surprising that most of the Supreme Court decisions construing the elements of RICO have come in civil cases, as private civil plaintiffs urged the federal courts to accept extremely broad interpretations of the elements of a RICO cause of action. ${ }^{131}$

The availability of super-enhanced sentences under $\S 924(c)$ appears to have had a similar effect in the federal criminal context. Federal prosecutors pushed the envelope on each of the various terms of the statute: "uses," "carries," "crime of violence," and "second or

of civil RICO suits). Note, however, that in 1995 RICO was amended to restrict its application in cases falling under the federal securities laws. Private Securities Litigation Reform Act of 1995, Pub. L. No. 104-67, § 107, 109 Stat. 737, 758 (amending 18 U.S.C. $§ 1964(c)$ ).

128. Douglas E. Abrams, Crime Legislation and the Public Interest: Lessons from Civil RICO, 50 SMU L. REV. 33, 36-37 (1996).

129. Lynch, supra note 127 , at 794.

130. See id. at 794-95 (stating that "the sprawling shapelessness of RICO create[d] the problem [and made] it relatively easy for plaintiffs to formulate a RICO cause of action"); see also ABRAMS \& BEALE, supra note 106, at 489 (noting that "[t]he current RICO statute now lists so many offenses as 'racketeering activity' that there is hardly an important federal crime that is not listed"). In the lower courts, RICO claims have been asserted in a remarkably broad range of complaints, involving, for example, the operation of a business during a bankruptcy proceeding, the conduct of a utility in rate proceedings, a trustee's conduct of estate, the procedures for obtaining a signature on a brokerage agreement, a dispute concerning the education provided by a beauty college, patent infringement and unfair competition, fees for architectural services, and a union's strike-related activities. NORMAN ABRAMS \& SARA SUN BEALE, FEDERAL CRIMINAL LAW AND ITS ENFORCEMENT 536-37 (2d ed. 1993).

131. See Nat'l Org. for Women, Inc. v. Scheidler, 510 U.S. 249, 256-62 (1994) (construing the term "enterprise"); Reves v. Ernst \& Young, 507 U.S. 170, 177 (1993) (construing the phrase "to conduct or participate" in the conduct of an enterprise's affairs through a pattern of racketeering activity); H.J., Inc. v. Northwestern Bell Tel. Co., 492 U.S. 229, 237 (1989) (construing the phrase "pattern of racketeering activity"). In addition, the Supreme Court also has rendered a number of decisions on the scope and applicability of the civil RICO cause of action. See, e.g., Holmes v. Sec. Investor Prot. Corp., 503 U.S. 258, 268-70 (1992) (holding that common law proximate cause rules are applicable to RICO cases); Tafflin v. Levitt, 493 U.S. 455, 456-58 (1990) (recognizing concurrent state and federal jurisdiction over civil RICO claims); Sedima, S.P.R.L. v. Imrex Co., Inc., 473 U.S. 479, 481 (1985) (holding that neither a prior criminal conviction nor separate racketeering injury is a prerequisite to civil liability). 
subsequent conviction." For example, until its amendment in 1998, $\S 924(c)(1)$ proscribed the "use"-but not the mere possession-of a weapon during a crime of violence or drug-trafficking offense. Federal prosecutors, seeking to extend the reach of the statute far beyond the obvious cases involving defendants who brandished or discharged a weapon, advocated an extremely broad interpretation of the term "use." Two of the most expansive theories advocated by the government were the gun fortress theory, which applied $\S 924$ (c) to the possession of guns in a house where drugs were also present, and the guns could be used to protect drugs, ${ }^{132}$ and the theory that a firearm was "used" when its possession "emboldened" a defendant committing a crime. Under these theories, enhanced penalties applied when a defendant possessed but made no active use of a firearm. In perhaps the most extreme case under the drug fortress theory, prosecutors charged that a paraplegic who was confined to a wheelchair "used" a firearm found hidden in the crawl space beneath his house. ${ }^{133}$ Many lower courts accepted such broad interpretations (and, in fact, the Ninth Circuit upheld the conviction of the paraplegic). ${ }^{134}$ Ultimately this line of cases was reversed by the Supreme Court's decision in Bailey v. United States, ${ }^{135}$ which held that under $\S 924$ (c) the term "use" reaches only the "active employment" of a firearm, not merely a potential for use. ${ }^{136}$

Because federal prosecutors had extended the statute so far beyond cases of "active employment," the Bailey decision substantially reduced the number of new prosecutions brought under $\S 924(\mathrm{c})$. It also created a wave of litigation in the lower courts, as federal prisoners challenged sentences imposed under broader interpretations of the statute. According to two major studies, limiting $\S 924$ (c) to the active use of a firearm excluded thousands of cases from the reach of its super-enhanced penalties. In a recent special report, the Bureau of Justice Statistics found that in the first month following the Bailey decision, fifty percent fewer defendants were prosecuted under $\S 924(\mathrm{c})$

132. For a discussion of the gun fortress theory, see 1 WELLING, BEALE \& BUCY, supra note 15, § 11.7(A), at 467; Angela LaBuda Collins, Note, The Latest Amendment to 18 U.S.C. $\$$ 924(c): Congressional Reaction to the Supreme Court's Interpretation of the Statute, 48 CATH. U. L. REV. 1319, 1350 (1999).

133. United States v. Torres-Medina, 935 F.2d 1047, 1048 (9th Cir. 1991) (describing the jury's verdict). For cases adopting the emboldening theory of possession, see Collins, supra note 132 , at $1351 \&$ n.202.

134. Torres-Medina, 935 F.2d at 1048.

135. 516 U.S. 137 (1995).

136. Id. at 143 . 
than in the last month prior to that decision, and it estimated that in the thirty-three months following Bailey, 2500 fewer defendants were charged with violating $\S 924(\mathrm{c}) .{ }^{1.7}$ Paul Hofer, a Senior Research Associate at the Sentencing Commission, concludes that the Supreme Court's decision affected even more cases; he estimates that "between 1500 and 2250 cases in a typical year were disqualified for Section 924(c) by the Bailey decision." "138 Because the Supreme Court gave Bailey retroactive application, holding that it could be raised by federal inmates on collateral review, ${ }^{139}$ Bailey also gave rise to challenges by those previously convicted of passive forms of "use." More than 10,000 persons were serving sentences under $\$ 924$ (c) at the time of the Bailey decision. ${ }^{140}$ Although there are no reliable figures on how many of those convictions have been reversed under Bailey, ${ }^{141}$ the decision certainly touched off a wave of litigation in the lower federal courts. ${ }^{142}$

Federal prosecutors also advanced other broad interpretations of $\S 924(c)$. They argued that a firearm was "used" within the meaning of $\S 924$ (c) when it was traded for drugs, ${ }^{143}$ and that a firearm was "carried" within the meaning of the statute when it was conveyed in a vehicle, even if locked in a trunk or glove compartment and thus not

137. Bureau of Justice Statistics, supra note 125, at 3.

138. Hofer, supra note 1, at 60-61 (emphasis added). It appears that Hofer's estimates include all cases that could have been charged under $\$ 924(\mathrm{c})$; but note that federal prosecutors do not employ $\S 924(\mathrm{c})$ in many of the cases where the facts would support such a charge. See infra Part II.B.

139. Bousley v. United States, 523 U.S. 614, 616 (1998).

140. Frank J. Murray, Justices Overturn Convictions Based on New Gun Use Ruling, WASH. TimES, Dec. 12, 1995, at A4.

141. Immediately after the ruling, a spokesman for the Justice Department estimated that the opinion would affect only "a few hundred cases." Id. That estimate seems low when it is compared to the percentage of new prosecutions affected by the ruling. On the other hand, most convictions are the result of a guilty plea, and a variety of procedural hurdles confront defendants who seek to overturn their convictions in collateral proceedings. See, e.g., Bousley, 523 U.S. at 623 (holding that a defendant who seeks to raise Bailey error on collateral attack after a guilty plea must establish "actual innocence" plus the absence of a knowing and intelligent plea); Lorentsen v. Hood, 223 F.3d 950, 952 (9th Cir. 2000) (holding that the Antiterrorism and Effective Death Penalty Act of 1996 barred relief for the defendant despite the government's stipulation that his conduct was insufficient to constitute "use" of a firearm under Bailey).

142. Bailey has been cited in more than 1699 cases in the lower federal courts, and Bousley (which held that Bailey can be applied retroactively) has been cited in approximately 598 cases. But those counts certainly include prosecutions brought after Bailey, as well as cases raising other issues. See Westlaw database search, KeyCite citing references to Bailey, from Dec. 6, 1995 to Feb. 15, 2002; Westlaw database search, KeyCite citing references to Bousley, from May 18, 1998, to Feb. 15, 2002.

143. Smith v. United States, 508 U.S. 223, 227-41 (1993). 
readily accessible. ${ }^{144}$ The Supreme Court accepted these arguments, broadening the reach of $\S 924$ (c) significantly. On the other hand, the Court rejected the government's argument that mandatory penalties under $\S 924(\mathrm{c})$ could be added to offense-specific firearm enhancements under the bank robbery and assault statutes. ${ }^{145}$

In other cases, prosecutors sought interpretations of the statute that would increase the sentences available in cases falling clearly within $\S 924(c)$. Section 924(c)(1)(C) imposes a mandatory minimum consecutive twenty-year term of imprisonment for any "second or subsequent offense." This clearly applies where a defendant who already has been convicted and served a sentence for a violation of $\S 924$ (c) commits a second offense after his release, but prosecutors sought to apply it to charges brought in a single indictment. In some cases, these charges were based upon separate incidents that occurred at different places and times. For example, in a case that reached the Supreme Court, the defendant committed six bank robberies, using a gun on each occasion, and was convicted and sentenced at a single proceeding to 105 years (including five years on the first $\S$ 924(c) count and twenty years on each of the other five "subsequent" counts under $\S 924(\mathrm{c}))$. ${ }^{146}$ In other instances, federal prosecutors argued that multiple violations - each requiring a mandatory consecutive term of at least twenty years-could be based upon the same predicate offense. ${ }^{147}$ In one case, the government charged the defendant with two predicate offenses, a cocaine conspiracy and managing a continuing criminal enterprise. Seven different guns were found at various locations, two of which had been discharged. ${ }^{148}$ How many $\S 924(\mathrm{c})$ counts did the government charge? Two, because two weapons were discharged? Seven, because the defendant possessed seven weapons?

144. Muscarello v. United States, 524 U.S. 125, 127-39 (1998).

145. See Busic v. United States, 446 U.S. 398, 399-400 (1980) (holding that a sentence for a $\S 924(\mathrm{c})$ violation may not be imposed in a prosecution for assault on a federal officer under 18 U.S.C. $\$ 111$, which provides for an enhanced sentence when a defendant "uses" a deadly weapon); Simpson v. United States, 435 U.S. 6, 16 (1978) (holding that a sentence for a § 924(c) violation may not be imposed in a prosecution for bank robbery under 18 U.S.C. $\$ 2113$, which provides for an enhanced sentence when robbery is committed "by use of a dangerous weapon or device"). These decisions were overridden by legislation enacted in 1984. See infra note 156.

146. Deal v. United States, 508 U.S. 129, 130-31 (1993).

147. For cases accepting the government's arguments, see, for example, United States $v$. Camps, 32 F.3d 102, 107 (4th Cir. 1994), and United States v. Lucas, 932 F.3d 1210, 1222-23 (8th Cir. 1991). For a discussion of the resolution of this issue in other circuits, see United States $v$. Anderson, 59 F.3d 1323, 1328-1331 (D.C. Cir. 1995) (en banc).

148. United States v. Lindsay, 985 F.2d 666, 677 (2d Cir. 1993) (reversing twelve of the fourteen convictions). 
No, fourteen, because he was charged with two offenses, and each of the seven weapons were charged separately in connection with each of the two offenses. ${ }^{149}$ (And of course the two charges of conspiracy and continuing criminal enterprise also overlap substantially, but that is another story.) In Deal v. United States ${ }^{150}$ a majority of the Supreme Court accepted the government's construction of the statute. ${ }^{151}$

This pattern suggests that federal prosecutors have responded to the incentive provided by the enhanced penalties provided under $\S 924(\mathrm{c})$, both by making $\S 924$ (c) the most frequently prosecuted federal firearms offense and by aggressively seeking to broaden its reach through expansive interpretations of its terms. Although previous studies have found that prosecutors are most strongly motivated by the likelihood of conviction, ${ }^{152}$ they also may respond to the likely penalty. This incentive may work not only at the level of individual prosecutors, but also at the level of departmental allocation of resources. As noted by the Administrative Office of U.S. Courts, a surge in the number of prosecutions between 1989 and 1991 appears to have been the result of the passage of legislation in 1988 increasing the penalties under that provision. ${ }^{153}$ Following passage, both the $\mathrm{Bu}-$ reau of Alcohol, Tobacco, and Firearms and the Department of Justice added significant personnel to handle these cases, and the number of prosecutions increased substantially. ${ }^{154}$ On the other hand, political agendas also drive prosecutorial policy. In 1991, the Department of Justice initiated Operation Triggerlock, ${ }^{155}$ which led to a major increase in the number of firearms investigations and prosecutions, and Triggerlock foreshadowed current initiatives, such as Project Exile.

Once federal prosecutors paved the way with expansive interpretations of $\S 924(\mathrm{c})$, Congress generally overrode each Supreme Court decision rejecting the government's interpretation. ${ }^{156}$ Most recently, in

152. For a discussion of the incentives driving prosecutorial behavior, see infra notes $165-72$ and accompanying text.

153. Walker \& Patrick, supra note 112, at 3.

154. Id.

155. See Bureau of Justice Statistics, supra note 125, at 4. For a description of Operation Triggerlock, see supra note 108 and accompanying text.

156. The decisions in Busic v. United States, 446 U.S. 398, 399-400 (1980), and Simpson v. United States, 435 U.S. 6, 16 (1978), were overruled by the Act of Oct. 12, 1984, Pub. L. No. 98-
} 
1998 Congress enacted legislation designed to "throttle criminal use of guns" ${ }^{157}$ to overrule the Supreme Court's decision in Bailey. ${ }^{158} \mathrm{Al}-$ though this legislation could be seen as an affirmation that the government's arguments correctly stated Congress's intent, it seems more likely that this legislation reflects the tough-on-crime politics of the time. ${ }^{159}$

\section{B. Underutilization of the Enhanced Penalties Under $\$ 924(c)$}

In the preceding Section, I argued that prosecutors had overused $\S 924(c)$, adopting an unusually aggressive litigation strategy to extend that section's reach beyond a natural reading of its language and the central justifications for its enactment. The pattern of prosecutorial efforts to expand the scope of $\S 924$ (c) to embrace additional cases stands in apparent contrast to another phenomenon: the deliberate decision by prosecutors not to invoke $\S 924$ (c) in many cases in which it is applicable. Several studies have documented the underutilization of $\S 924(\mathrm{c})$. In 1991, the Sentencing Commission concluded that $\S 924$ (c) was applied in only forty-one percent of the bank robbery and drug-trafficking cases in which it was applicable. ${ }^{160}$ The Commission documented what it characterized as the evasion of both statutory and Guidelines enhancements. In field studies, Stephen J. Schulhofer and Ilene Nagel found that federal prosecutors often engaged in charge bargaining in which they agreed not to bring, or to dismiss, charges under $\S 924(\mathrm{c}){ }^{161}$ More recently, the Commission concluded that in 1995 less than half of the defendants responsible for the use of a firearm actually received an increased sentence under $\S 924(\mathrm{c})$. $^{162}$

Laying aside the evidentiary problems that may arise in individual cases, there are two principal reasons defendants are not sen-

$473, \S 1005$, 98 Stat. 1837,2138 , which makes the enhanced sentence available in the case of "a crime of violence which provides for an enhanced punishment." Id.

157. Act of Nov. 13, 1998, Pub. L. 105-386, 112 Stat. 3469, 3469.

158. See supra notes $135-36$ and accompanying text.

159. For a description of the political environment for federal criminal legislation, see generally Beale, supra note 85 .

160. U.S. SENTENCING COMM'N, SPECIAL REPORT to CongRess: MANDATORy Minimum Penalties in the Federal Criminal JustiCe System 53 (1991).

161. Stephen J. Schulhofer \& Ilene H. Nagel, Negotiated Pleas Under the Federal Sentencing Guidelines: The First Fifteen Months, 27 AM. CRIM. L. REV. 232, 272-78 (1989).

162. The Commission concluded that between twenty-four and forty-four percent of the defendants eligible for an enhancement under $\$ 924$ (c) received an enhanced sentence under that provision. Hofer, supra note 1 , at 55. Because of the sample size, the Commission's data had a margin of error of plus or minus ten percent. $I d$. 
tenced under $\S 924$ (c) in cases that fall within the statute. One is that $\S 924$ (c) charges are frequently employed as a bargaining chip. ${ }^{163}$ Since 1995 , charges under $\S 924$ (c) have been dismissed in more than half of the cases in which a defendant pleaded guilty. ${ }^{164}$ Although any charge can be used as a bargaining chip, the super-enhanced penalties required under $\S 924$ (c) give prosecutors terrific leverage in plea bargaining. The minimum value of the dismissal of a charge under $\S 924(\mathrm{c})$ is a five-year sentence reduction, and when a second or subsequent offense is involved, the minimum value of dismissal is a twenty-five-year sentence reduction.

The employment of $\S 924$ (c) as a bargaining chip is not inconsistent with prosecutors' efforts to expand the scope of that provision, since $\S 924$ (c) has more value in bargaining if it is applicable in more cases. Moreover, although prosecutors do care about sentence length ${ }^{165}$ they care most of all about obtaining convictions. ${ }^{166}$ Given that priority, prosecutors should predictably exploit charges under $\S 924$ (c) to obtain guilty pleas and avoid the possibility of acquittals. The data support the hypothesis that prosecutors are using $\S 924$ (c) to improve conviction rates. Since 1993, when the policy of the Department of Justice gave federal prosecutors greater leeway to bargain with charges under $\S 924(\mathrm{c}){ }^{167}$ both the rate of dismissal of charges

163. Prior to 1993, Department of Justice policy seemed to preclude charge bargaining, though the practice certainly occurred. In 1993 the attorney general issued a memorandum that authorized more flexibility. Memorandum from Janet Reno, U.S. Attorney General, to Holders of U.S. Attorneys' Manuals, tit. 9 (Oct. 12, 1993), reprinted in 6 FED. SENTENCING REP. 352 (1994). For a discussion of the prior prosecutorial practice and the Reno memorandum, see generally Sara Sun Beale, The New Reno Bluesheet: A Little More Candor Regarding Prosecutorial Discretion, 6 FED. SENTENCING. REP. 310 (1994).

164. Bureau of Justice Statistics, supra note 125, at 6 tbl.5 (reporting dismissal rates ranging from $50.3 \%$ to $65.7 \%$ from 1995 to 1998 ).

165. Scholars applying an economic model have assumed that prosecutors place a value on sentence severity as well as conviction. The seminal study is William M. Landes, An Economic Analysis of the Courts, 14 J.L. \& ECON. 61 (1971), which posits that the prosecutor seeks "to maximize the expected number of convictions weighted by their respective [sentences] ... subject to a constraint on the resources or budget available to his office." Id. at 63 .

166. See, e.g., EISENSTEIN, supra note 98, at 152-53 (arguing that "[t]he need to win cases constitutes the strongest incentive in the work environment" of federal prosecutors); George T. Felkenes, The Prosecutor: A Look at Reality, 7 Sw. U. L. REV. 98, 121 (1975) (suggesting that prosecutors develop a "conviction psychology"); Daniel C. Richman, Old Chief v. United States: Stipulating Away Prosecutorial Accountability?, 83 VA. L. REV. 939, 967-68 (1997) (identifying an inescapable environmental pressure to maximize convictions that affects both state and federal prosecutors). Prosecutors also place substantial value on the credibility they obtain by avoiding defeats. Id. at 969 (citing Jerome H. Skolnick, Social Control in the Adversary System, 11 J. CONFLICT RESOL. 52, 57 (1967)).

167. See supra note 163 and accompanying text. 
under $\S 924(c)$ and the rate of convictions in the cases in question have increased significantly. ${ }^{168}$

Though they sought to extend the reach of $\S 924(c)$ to additional cases, federal prosecutors have refused to charge $\S 924$ (c) in many cases falling within its ambit when they deemed the mandatory sentence enhancements to be unnecessarily or unduly harsh. Because the penalty under $\S 924(\mathrm{c})$ is mandatory, prosecutors cannot tailor its application to a case once they invoke it, and its effect is unusually severe. Thus the same factors that encourage prosecutors to seek enlarged coverage to bring more cases within the terms of $\S 924$ (c) also serve as a disincentive for invoking that provision, even in cases that fall squarely within its ambit. In this respect, the behavior of prosecutors is radically different from their civil counterparts in the private bar, who have both an incentive and a clear professional responsibility to seek the maximum recovery for their clients. For a civil plaintiff, another dollar is always a benefit, and one would predict that counsel would forgo or dismiss civil charges that would increase the client's recovery significantly only for tactical reasons (and certainly not because of an equitable sense that a larger award would penalize the defendant too much). In contrast, prosecutors are expected to do justice, a duty that does not necessarily translate into seeking the harshest possible penalties in every case. ${ }^{16}$

This "reverse sentencing effect," in which high penalties decrease conviction rates rather than increasing them, has appeared elsewhere. When penalties are deemed to be too high, prosecutors (as well as police and jurors) may become reluctant to impose them. ${ }^{170}$ This phenomenon, observed in the United States and England, occurs especially when officials and the public have not become accustomed to new higher penalties. ${ }^{171}$

Both the rate of bargaining dismissals and the reluctance to invoke $\S 924$ (c) have increased as Congress has raised both the mandatory sentences under that provision and the severity of federal sen-

168. See Bureau of Justice Statistics, supra note 125, at 6 tbl.5 (noting that, since 1994, the dismissal rate has been more than $50 \%$ each year, and conviction rates, which had ranged from $74.4 \%$ to $77.6 \%$, increased steadily from $80.8 \%$ to $83.1 \%$ ).

169. See, e.g., Gerard E. Lynch, Our Administrative System of Criminal Justice, 66 FORDHAM L. REV. 2117, 2127 (1998) (asserting that prosecutors typically see themselves as public officials making a decision that encompasses determining the "appropriate" sentence, rather than necessarily seeking to maximize jail time).

170. Neal Kumar Katyal, Deterrence's Difficulty, 95 MicH. L. ReV. 2385, 2450-51 (1997).

171. Id. at 2451-52 (describing examples from various states and from England, and positing a "lag of lore" theory). 
tences as a whole. Increased severity has raised the stakes in individual cases and increased the gap between past practices and the mandatory statutory regime to the point that prosecutors feel real reluctance to apply $\S 924$ (c) (and mandatory minimum drug provisions) in many cases.

Thus the super-enhancement of the sentence available under $\S 924$ (c) has increased the incentives for prosecutors both to extend the coverage of the statute, pressing on the definitional boundaries, and to bargain away charges under the statute, or, in certain cases, to decline to bring charges under the statute. In contrast to Congress's intention that $\S 924$ (c) be a mandatory provision that offenders know they cannot evade, that section has been left unused in the majority of federal prosecutions where the facts appear to fall within its ambit. Because the super-enhanced penalties under $\S 924$ (c) are so severe, this expansion of the prosecutors' discretion has two consequences: it increases the prosecution's leverage to compel defendants to plead guilty to predicate offenses, and it allows prosecutors to determine which defendants will receive sentences enhanced under $\S 924(c)$ and which defendants' sentences will not be enhanced under that section, although they could be.

This state of affairs is troubling for several reasons. It creates a huge gap between the sentences imposed on the minority of defendants, who are prosecuted and sentenced under $\S 924(\mathrm{c})$, and the majority, who are not. The prosecutors' largely uncontrolled discretion in deciding whether to invoke or to bargain away charges under $\S 924(c)$ generates concerns both for the fairness of the process ${ }^{173}$ and the reliability of the convictions obtained when charges under $\S 924(c)$ are bargained away. As in the case of other mandatory minimums, the gun legislation actually undermines the uniformity that was the goal of the Sentencing Guidelines regime. ${ }^{174}$ Indeed, as

172. Stephen J. Schulhofer \& Ilene H. Nagel, Plea Negotiations Under the Federal Sentencing Guidelines: Guideline Circumvention and Its Dynamics in the Post-Mistretta Period, 91 Nw. U. L. REV. 1284, 1309-10 (1997); see also supra notes 170-71 and accompanying text (discussing the reverse sentencing effect and the "lag of lore" theory).

173. For a discussion of the potential for unfairness in the exercise of discretion by federal prosecutors, see generally Sara Sun Beale, Too Many and Yet Too Few: New Principles to Define the Proper Limits for Federal Criminal Jurisdiction, 46 HASTINGS L.J. 979 (1995); Stephen D. Clymer, Unequal Justice: The Federalization of Criminal Law, 70 S. CAL. L. REV. 643 (1997).

174. See U.S. SENTENCING COMM'N, MANDATORY Minimum PenAlties IN THE Federal CRIMINAl Justice System: A SPECIAL RePORT to CONGRESS 89 (1991) (identifying two types of disparities: first, defendants charged with similar offenses may not be sentenced under a mandatory minimum, depending on variables such as race, circuit, and prosecutorial practice; 
Stephen Schulhofer notes, the Sentencing Commission's own data in the early 1990s indicated a troubling racial disparity, with white defendants less likely to be subject to mandatory minimum penalties than black or Hispanic defendants. ${ }^{175}$ Moreover, overbroad mandatory minimum penalties also create special hazards to accuracy in a plea bargaining regime, insofar as super-enhanced penalty provisions give prosecutors an unchecked opportunity to overcharge and generate easy pleas. ${ }^{176}$ This excessive plea leverage reduces the prosecutors' incentive to separate innocent from guilty defendants at the charging stage ${ }^{177}$ increasing the chance that innocent defendants will be convicted.

\section{CONCLUSION}

Congress's efforts to respond to gun violence have had farreaching effects within the federal system. The legislative efforts to expand the boundaries of federal criminal jurisdiction to deter and punish gun violence brought Congress to the threshold of a major shift in the federal-state boundary. The Supreme Court responded with its first decision in half a century limiting congressional power under the Commerce Clause. This historic decision seems to have been motivated to a significant degree by the Court's institutional concerns about a possible flood of federal gun prosecutions. Federal prosecutors also have pressed the courts for broader interpretations of the elements of the principal federal firearms enhancement statute, generating an unusually large volume of litigation. Although prosecutors were not always successful in this litigation, Congress stepped in when the courts denied the prosecutors. At the same time as prosecutors have expanded the statutes' applicability, though, they have declined to impose the mandatory penalties in the majority of cases falling within the terms of the statute. This surprising pattern of underutilization results from prosecutors' tactical dismissal of charges in plea bargaining and their refusal to bring charges in other cases. Where the super-enhanced gun penalties available under federal law are employed in plea negotiations, they give prosecutors greatly in-

and second, that defendants charged with dissimilar offenses and having dissimilar roles in the offense often get similar reduction).

175. Stephen J. Schulhofer, Rethinking Mandatory Minimums, 28 WAKE FOREST L. REV. 199, 218 (1993) (citing U.S. SENTENCING COMM'N, supra note 174, at 81-82).

176. Robert E. Scott \& William J. Stuntz, Plea Bargaining as Contract, 101 YALE L.J. 1909, 1963-67 (1992).

177. Id. 
creased leverage. In cases falling within $\S 924(\mathrm{c})$ prosecutors can make offers that defendants cannot refuse, because the price of refusal may be a mandatory consecutive sentence of five, twenty-five, or even one hundred years. In many other cases, however, prosecutors decline to apply federal enhancement statutes where the penalties seem-to the prosecutors - to be unduly harsh. Thus the effect of enhancing the penalties applicable to gun-related crime has been to enlarge greatly the scope of the discretion exercised by federal prosecutors and the magnitude of the consequences controlled by their discretion, without the development of any additional checks against the abuse of this enhanced discretion.

It is far from clear that enhanced gun penalties achieve their intended purposes of deterring crime and incapacitating dangerous criminals. ${ }^{178}$ Even if they miss the mark and have little effect on offenders, the federal gun laws have had a significant impact within the federal system, creating a backlash from the Supreme Court that may tie the hands of Congress in the future, and creating perverse incentives for prosecutors that result in greater inequity among defendants as a result of mandatory sentencing provisions. More subtle changes also may have been set in motion, as federal prosecutors seek to handle the crush of new gun cases by wholesale cross-designation of state prosecutors, setting a precedent for the delegation of federal prosecutorial authority to local actors.

178. See Hofer, supra note 1, at 43 (noting that most studies find that firearms enhancement laws have no impact) 